\title{
Urban Metabolism and the UM-US-SC Nexus
}

\author{
Tong Zou ${ }^{1}$ \\ ${ }^{1}$ The University of New South Wales, Sydney, Australia \\ Correspondence: Tong Zou, The University of New South Wales, Sydney, Australia. Tel: 133-5006-5598
}

Received: October 25, 2019

Accepted: November 15, 2019

Online Published: November 19, 2019

doi:10.20849/ajsss.v4i4.671

URL: https://doi.org/10.20849/ajsss.v4i4.671

\begin{abstract}
This paper discusses the current increasing trend of urbanization and environmental implications of urbanizations, potential solutions for the problems caused by overpopulation \& urbanization. Global challenges like rapid population growth, resource scarcity, climate change, biodiversity loss are the centres of environmental management issues as well. As cities are recognized as the key to resolve these global environmental issues and sustainability are the main focuses of this century's development, this paper identifies the sustainability of cities or urban sustainability (US) as the fundamental principal or core idea underlying possible pathways to solve those major challenges with an emphasis on urban metabolism (UM) (Section 2 6). The literature review covers the evolution and development of UM concept, metaphors of UM perspective, definitions of UM, its applications, challenges and future directions. Six types of UM methodologies are discussed as well. This paper demonstrates that UM is a promising approach for building US and connects it to the concept of smart cities (SC). Relating contents like the differences and connections between smart cities and sustainable cities, the politics of data, opportunities \& challenges of SC are presented in Section 7. The last part of this paper proposes a Nexus among UM, US and SC; which reveals both of the apparent and underlying correlations \& interactions among these three concepts and their practices.
\end{abstract}

Keywords: urban metabolism, smart cities, sustainable development, urban sustainability, circular urban metabolism

\section{Preamble}

This research paper reviews recent literature on the concept of Urban Metabolism (UM) and explores how it can be framed by wider concerns and objectives including sustainability goals, urban development, resource management and environmental protection. After a general introduction to urbanisation issues, the paper draws on conceptual literature and previous reviews of UM applications to explore the foundations, practices, limitations and future researches of UM, leading to a discussion of the nexus between UM, Urban Sustainability and Smart Cities.

\section{Introduction}

\subsection{Urbanization and Environmental Implications}

\subsubsection{Urbanization \& "The Anthropocene Era"}

It is often argued that anthropogenic activities and their related negative environmental impacts have been very pervasive and profound factors for the development of earth systems in this Anthropocene Era (Dijst et al., 2018; Steffen et al., 2017; IPCC, 2014). Nowadays, human beings have become the most influential power in moving materials all over the planet with the rise of industrialization and urbanization (Klee \& Graedel, 2004).

In the book Sustainable Urban Metabolism, Ferrão \& Fernández (2013) argued that the world we homo sapiens live in rapidly changing, modifying ways of living and disturbing a general sense of stability. They noted that the trends of globalization \& urbanization stimulated by accelerating technological advancement appear to be the key drivers of these unstable changes for the past ten decades. There is a mutual correlation between them: as globalization gets faster, urbanization grows more rapid. As a result, urban systems have been playing an essential role as "growth engines" for their regional economies and this reveals the reason why most of the global population lives in cities now (Ferrão and Fernández, 2013). Grübler and Fisk claimed that urban Gross Domestic Product (GPD) stands for nearly $80 \%$ of world GDP (United Nations, 2013). The combination of economic growth and urbanisation has been the central driver for employment creation, innovation and cultural exchange ( UN, 2013). 
According to the United Nations (2013), over 50\% of world's population has been living in the cities since 2007. It is expected that there will be 39 megacities in the world for a combined total of 685 million people by 2020 (Kennedy et al., 2014) and 70\% of global population will live in cities by 2050 (Thomason \& Newman, 2018; Rosado et al., 2016). Moreover, $80 \%$ of world's population will live in developing countries \& regions in 2050 and crowd in cities of Africa and Asia ${ }^{5}$. As can be seen, global urbanization is proving irreversible (Ferrão and Fernández, 2013) and the impacts of global urbanization on the environment are significant and inevitable.

\subsubsection{Environmental Implications of Urbanization}

Melosi (2010) argues that cities are major modifiers of the physical environment. Humanity's ecological deficit is consequently simultaneously increasing with worldwide urbanization (Moore et al., 2013). Urbanization has both positive and negative environmental implications which are related to the wastefulness of many cities and urban sustainability multipliers in the economies of agglomeration and economies of scale (Moore et al., 2013).

According to Sun et al. (2016), cities are responsible for more than $60 \%$ of global energy consumption and $75 \%$ of greenhouse gas (GHG) emissions. Cities' demand is increasing, and the ecological footprint of humanity grows much greater than the biocapacity of the planet; thus, the demand for biocapacity is continuously increasing (Moore et al., 2013). It is believed that rapid urbanization \& growing population in the cities will raise resource requirement, increase social inequality for urban dwellers and escalate environmental impacts expanse over city boundaries to their hinterlands (Musango \& Robbinson, 2017).

Thomason \& Newman (2018) support the above assessments that the present human generation is facing unprecedented global major challenges including rapid population growth, resource scarcity, climate change, biodiversity loss, increasing consumption patterns, and social inequity. They argue with others, that some grand challenges can be solved by regional solutions as a manifestation of cities' contribution to sustainability (Thomason \& Newman, 2018; Cui, 2018). For instance, resource scarcity can be solved by efficient material uses; climate change could be mitigated or solved by reducing energy use; compact city footprints can be a solution to biodiversity loss \& encroachment upon rural land and so on (Cui, 2018). In addition, Beloin-Saint-Pierre et al. (2017) also argued that urban activities are managed at sub-national level and effective sub-national level actions could help us address global environmental issues. In the opinion of Thomason \& Newman (2018), cities hold the key to tackle those global major challenges since not only their current impacts can be reduced but also past impacts can be regenerated by cities. They introduced the concept of regenerative city as a city not only reduce its ecological footprint but also has the following three key features: a) renewable energy systems; b) an environmentally enhancing, restorative relationship between the urban systems and the natural systems they depend on; c) new lifestyle choices \& economic opportunities which will encourage people to participate in this transformation (Thomason \& Newman, 2018). This implies the potential of transiting from linear urban metabolism into circular urban metabolism, which may be the best chance for achieving the planetary sustainability. Furthermore, the Sustainable Development Solutions Network (SDSN) (2013) showed that cities play an essential role in the ability of nations of achieving sustainable development (SD) and others have also argued that US is essential, primal and indispensable since cities are dynamic and complex ecosystems that shape the world (Newman, 1999).

In spite of irreversible global urbanization and global major challenges which the present human generations are facing, there is still a silver lining that the negative impacts of urbanization are not irrevocable. Cities may be the core part of the solution and the key to a promising sustainable future of the planet. Meanwhile, urban metabolism (UM) is the "magic box" where this key can be found.

The above introduction to global urbanization and its impacts now leads to more detailed exploration of the UM concepts and practices.

\section{Evolution and Development of UM Concept}

\subsection{The Foundations of UM Concept}

On the authority of Musango \& Robbinson (2017), there is no consensus in the literature on the foundations of the concept of urban metabolism (UM). For example, Kennedy et al (2011) highlighted Abel Wolman (1965) as the founder of the UM concept when he examined the process of supplying material, energy \& food to a hypothetical city, as well as its respective output products. While Lederer \& Kral (2015) argued that Theodor Weyl (1864) as the founder of current UM studies.

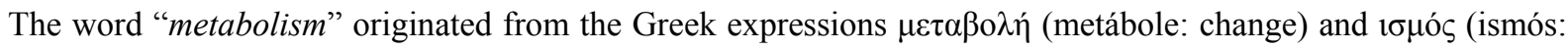
process or state) (Céspedes Restrepo \& Morales-Pinzón, 2018). In 1883, Karl Marx applied the concept of metabolism to demonstrate the material and energy exchange between nature and society (Zhang, 2013) and later 
he used the term "social metabolism" in his publication "Capital" in 1859 (Céspedes Restrepo \& Morales-Pinzón, 2018). In 1839, Theodor Weyl published "Essays on the metabolism of Berlin" and examined nutrient flows outputted from Berlin, comparing them to nutrient consumption through food intake (Céspedes Restrepo \& Morales-Pinzón, 2018). In 1965, Abel Wolman's articles "the metabolism of the cities" caught a lot of attention in the academia by virtue of the significance of the research results as well as the potentials of UM for analyzing cities (Céspedes Restrepo \& Morales-Pinzón, 2018). After Wolman's work for a hypothetical city, in the 70s three UM studies for real cities (Tokyo, Brussels and Hong Kong) were conducted by experts from different fields of study like chemical engineering, ecology and civil engineering (Brunner \& Rechberger, 2004; Kennedy et al., 2011), which emphasized the fact that UM is an interdisciplinary subject ${ }^{16}$. Indeed, UM can be considered as a boundary concept to bridge the discourses of Marxist ecology (inequality), urban ecology (socio-ecological systems) and industrial ecology (energy \& material flows) (Newell \& Cousins, 2015).

In 1970, Howard Odum established the principal of hierarchy of the energy, the basis for Emergy Analysis in his article "Environment, power and society" (Kennedy et al., 2011). Later in 1991, Peter Baccini and Paul Brunner consolidated the method Material Flow Analysis and presented its application in the book Metabolism of the Anthroposphere (Musango \& Robbinson, 2017; Céspedes Restrepo \& Morales-Pinzón, 2018). Those two methods then have evolved and become the two main schools for UM analysis today (Céspedes Restrepo \& Morales-Pinzón, 2018).

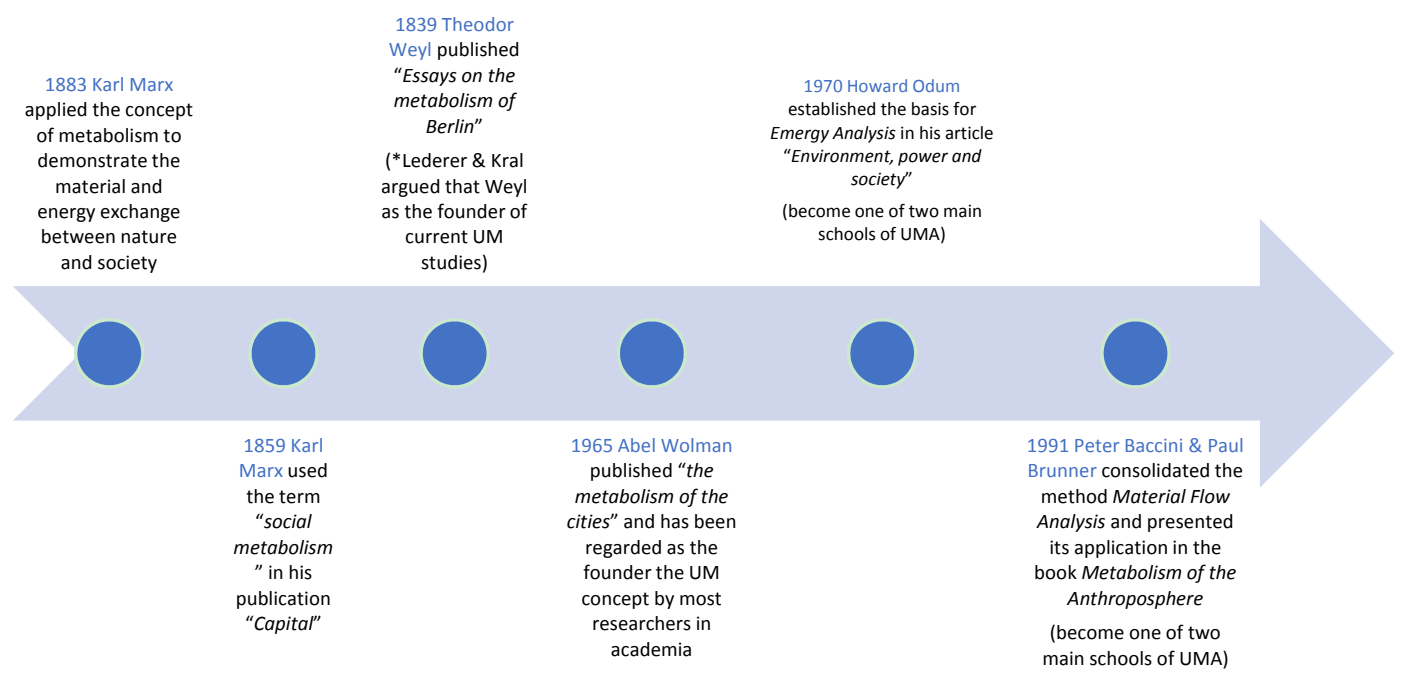

Figure 1. Illustrates the relevant events for the foundations of UM concept

\subsection{Two Central Metaphors of UM Perspective}

\subsubsection{Organism Metaphor vs. Ecosystem Metaphor}

As we all know, UM perspective employ metaphors on cities for a better understanding \& more effective analysis of urban systems. One of the two central metaphors utilized in an UM perspective on cities is an organism metaphor. In an organism metaphor, cities are seen to share attributes with organisms in their distribution resources through networks: cities are likened to a human body (Golubiewski, 2012). The organism metaphor represents the present conformation of city metabolism, which is most linear (Musango \& Robbinson, 2017).

On the other hand, cities can be considered as ecosystems for solving the environmental problems which are mainly related to the increasing inputs and outputs of energy and material (Newman, 1999). William Rees (2013) argued that "the 'urban ecosystem' consists of the assemblage of nonhuman species in the city, and the purpose of inquiry is to determine how these species have adapted to the structural and chemical vagaries characteristic of the 'built environment."'. As maintained by Musango \& Robbinson (2017), an ecosystem perspective is appealing as it widens the scope of inquiry to include relationships between actors \& between other system elements and is embraced by managers and the general public. Furthermore, Melosi (2009) stated that it is a possible way to minimize the intellectual gap between nature \& cities by extending an "urban systems" beyond its borders, connecting cities more often to their hinterlands, and inquiring the intention behind urbanization \& expansion. This type of metaphor represents resource efficiency and closed loops which are circular since all outputs are potential inputs (Musango \& Robbinson, 2017). 


\subsubsection{Linear UM vs. Circular UM}

When the concept of UM was firstly applied to assess urban metabolic process, a linear UM model that comprises input and output processes was employed by Wolman (1965). An alternative model, - circular or cyclical UM was proposed by Girardet (1990) who argued that a linear pattern from a city's input of material and energy to its output of wastes didn't precisely imitate how actual organisms influence Earth's life-support system (Zhang, 2013). This point of view was also agreed by Duan (2004); he argued that urban metabolic process is too long with inefficient and insufficient circulation and flows of materials and energy contrast to a natural urban metabolic process.

Cities depend on their hinterlands for materials including biomass, water, construction materials \& energy requirements (Bai, 2007), which increases their vulnerability owing to inefficient use of imported materials and the present ongoing linear UM (Musango \& Robbinson, 2017). Linear UM foists pressures on local resource supplies and causes negative environmental impacts throughout the process of exploiting resource and discarding wastes (Musango \& Robbinson, 2017). On the other hand, Musango \& Robbinson (2017) propose that circular UM simulates a real natural ecosystem with efficient consumption, recycling, reducing and reusing fluxes of resources \& materials which results in decreasing a city's dependence on their hinterlands \& other cities. Thus, it can be argued that circular UM which represented by ecosystems metaphor offers a stronger prospect for achieving urban sustainability.

\subsection{Definitions of UM}

UM are defined variously by several researchers and scholars. However, there is no universally acknowledged definition of UM in academia. Since there are two different metaphors of UM perspective (See Section 3.2) and the concept of UM has been continuously evolving since Wolman firstly introduced it in 1965. Table 1 shows different definitions of UM. Due to the multidisciplinary nature of UM, the concept of UM has been understood and interpreted into several diverse definitions by various scholars and researchers from different fields. As a result, the differences between different definitions are significant.

Table 1. Different definitions of UM

\begin{tabular}{|c|c|c|c|}
\hline Definition of UM & $\begin{array}{l}\text { Authors, } \\
\text { Year }\end{array}$ & Article & Comments \\
\hline $\begin{array}{l}\text { All the materials and commodities needed } \\
\text { to sustain the city's inhabitants at home, at } \\
\text { work and at play. }\end{array}$ & $\begin{array}{l}\text { Abel } \\
\text { Wolmam, } \\
1965\end{array}$ & $\begin{array}{l}\text { The metabolism of } \\
\text { cities }\end{array}$ & $\begin{array}{l}\text { The first definition of } \\
\text { UM }\end{array}$ \\
\hline $\begin{array}{l}\text { Sum of the technical and socio-economic } \\
\text { processes that occur within the cities, } \\
\text { resulting in growth, production of energy, } \\
\text { and elimination of waste. }\end{array}$ & $\begin{array}{l}\text { Kennedy et } \\
\text { al., } 2007\end{array}$ & $\begin{array}{l}\text { The changing } \\
\text { metabolism of cities }\end{array}$ & $\begin{array}{l}\text { The most cited } \\
\text { definition of UM }\end{array}$ \\
\hline $\begin{array}{l}\text { Collection of complex socio-technical and } \\
\text { socio-ecological processes by which } \\
\text { flows of material, energy, people, and } \\
\text { information shape the city, service the } \\
\text { needs of its populace, and impact the } \\
\text { surrounding hinterland. }\end{array}$ & $\begin{array}{l}\text { Currie and } \\
\text { Musango, } \\
2017\end{array}$ & $\begin{array}{lr}\text { African urbanization: } \\
\text { assimilating urban } \\
\text { metabolism into } \\
\text { sustainability discourse } \\
\text { and practice }\end{array}$ & $\begin{array}{l}\text { The most } \\
\text { comprehensive } \\
\text { definition of UM }\end{array}$ \\
\hline $\begin{array}{l}\text { The network of heterogeneous flows of } \\
\text { goods, services, materials and energy in } \\
\text { cities. }\end{array}$ & $\begin{array}{l}\text { Dijst et al., } \\
2018\end{array}$ & $\begin{array}{l}\text { Exploring urban } \\
\text { metabolism-Towards } \\
\text { an interdisciplinary } \\
\text { perspective }\end{array}$ & $\begin{array}{l}\text { The latest description } \\
\& \text { understanding of } \\
\text { UM }\end{array}$ \\
\hline
\end{tabular}

\subsubsection{Milestones of UM Studies}

Cities or urban systems have great negative impacts and heavy pressures on the environment and their hinterlands. Thereby, UM studies have attracted more and more attentions and become one of the main concerns for both academia and government. Looking back, there are several milestones in the development of both theory and practical approach of UM studies, for example: 
- Karl Marx has been cited as the first to discuss urban sustainability assessment and used metabolism to describe the flows between the natural world and social systems for his critical review of industrialization (Marx, 1981; Zhang, 2013; Beloin-Saint-Pierre et al., 2016).

- In 1965, Abel Wolman re-established the concept of UM to conduct a study regarding declining air and water qualities in American cities (Zhang, 2013).

- Baccini (1997) outlined several merits of SD for an ecologically sustainable UM as the follows:

a) The development is based only on renewable resources: the rate of consumption of resources should not exceed the rate at which those resources can be replenished.

b) The development maintains the "genetic pool": it does not diminish biological diversity.

c) The development does not lead to systems that narrow the freedom of future generations by leaving to those generations polluted aquatic \& terrestrial ecosystems.

- In 2008, "urban metabolism: measuring the ecological city" was used as the theme of the international ConAccount conference and the global influence of UM studies was realized and explored (Zhang, 2013; Havránek, 2009). ConAccount is a network of institutions working on Material Flow Analysis (MFA) which has the following purposes:

a) To support the information exchange between the scientists developing MFA and the users of the results

b) To support the development of a coherent framework of MFA methodologies

c) To promote the application and implementation of MFA (Harvránek, 2008).

- In 2017, Kenney et al. proposed the definition of UM as: "the sum total of the technical and socioeconomic processes that occur in cities, resulting in growth, production of energy, and elimination of waste". Although this is the most cited definition in literature, it's not utilized and followed by past and present quantitative studies of UMs on every occasion as some studies contemplate facets beyond the city limits or only some particular flows (Beloin-Saint-Pierre et al., 2016; Musango \& Robbinson, 2017).

\subsubsection{Urban Metabolism Assessment (UMA)}

García-Guaita et al. (2018) argued that UM remains as a conceptual approach with significant variations between studies regarding the materials energy sources \& pollutants included in individual assessments. This raises practical questions about how to 'operationalise' UM as a tool for environmental problem solving.

UM has the potential to be an integrated platform from which to assess social-ecological systems within the concept and practice of sustainability (Céspedes Restrepo \& Morales-Pinzón, 2018). It represents the "sum of the technical and socio-economic processes that occur within the cities, resulting in growth, production of energy, and elimination of waste" (Kennedy et al., 2007). Therefore, in practice UM can provide a better understanding of its material and energy fluxes, wastes generations, environmental impacts, the dynamics of socio-economical, socio-ecological, and socio-technical processes.

According to Beloin-Saint-Pierre et al. (2017), there are four types of fluxes in UM systems and two types of data for UM modelling. For UM fluxes, economic \& process fluxes indicate the connections between various components of an UM while material \& energy fluxes indicate both the connections \& impacts of UMs on the environment (Beloin-Saint-Pierre et al., 2017). As for data used in UM model systems, Beloin-Saint-Pierre et al. (2017) pointed out that $65 \%$ of his reviewed UM studies were using top-down data and more than $20 \%$ were using bottom-up data which was mostly found in the process-based Life Cycle Assessment (LCA). Additionally, Dijst et al. (2018) categorized five inter-related elements of UM includes drivers (D), needs (N), facilitator/constraints $(\mathrm{F} / \mathrm{C})$, activities $(\mathrm{A})$, flows \& stock (F\&S). F\&S often connected with problems facing UM and evaluating D, N, F/C could provide potential solutions for those problems (Dijst et al., 2018). It is not hard to tell that the ways of classifying UM variables \& selecting indicators for urban metabolism assessments (UMAs) greatly outnumber the ways of defining UM in practice.

The above sections explored the development \& evolution of UM concepts and introduced UMA, now the paper will discuss UM practices and various UMA methods in details.

\section{Research Methodologies Based on Urban Metabolism in Practice}

\subsection{Variation of UMAs}

As a result of lacking standardization, various Urban Metabolism Assessments (UMAs) have been developed to account for UM flows (García-Guaita et al., 2018). There are six main types of research approaches based on UM 
or UMA, respectively. They are accounting methods, Input-Output Analysis (I/O A), Ecological Footprint Analysis (EFA), Life Cycle Assessment (LCA), simulation methods and hybrid methods. For accounting methods, there are four different types: Material Flow Analysis (MFA), Economy-Wide Material Flow Analysis (EW-MFA), Substance Flow Analysis (SFA), and Emergy Analysis (EA). Of the above approach, EFA, MFA and LCA are macro tools developed from the realm of industrial ecology for assisting the design of sustainable urban systems (Ferrão \& Fernández, 2013). Table 2 illustrates the typology for UMAs.

Table 2. Typology for urban metabolism assessment

\begin{tabular}{|c|c|c|}
\hline \multicolumn{2}{|l|}{ UMA } & Description \\
\hline $\begin{array}{l}\text { Accounting } \\
\text { Methods }\end{array}$ & $\begin{array}{l}\text { Material Flow } \\
\text { Analysis } \\
\text { (MFA) }\end{array}$ & $\begin{array}{l}\text { MFA can lay a foundation for material flow management \& dematerialisation } \\
\text { strategies at city level, make contribution to public environmental } \\
\text { policymaking (Musango \& Robbinson, 2017), and trace hidden material flows } \\
\text { which provides a better understanding of environmental impacts \& pressures } \\
\text { (Zhang, 2013). MFA totals up the amount of different materials straightway, } \\
\text { but this method is not able to distinguish the quality differences among } \\
\text { different materials (Sun et al., 2016). Because of this, MFA is not able to } \\
\text { assess the cities' degree of sustainability properly as well as the alterations \& } \\
\text { differences in sustainability (Zhang, 2013). }\end{array}$ \\
\hline & $\begin{array}{l}\text { Economy-Wide } \\
\text { Material Flow } \\
\text { Analysis } \\
\text { (EW-MFA) }\end{array}$ & $\begin{array}{l}\text { EW-MFA is the most well-developed and widely used approach, it can make } \\
\text { benefits to the definition of public environmental policies (Musango \& } \\
\text { Robbinson, 2017) and contribute to material flow management \& } \\
\text { dematerialization strategies on a regional-level or city-level (Barles, 2009). }\end{array}$ \\
\hline
\end{tabular}

Substance Flow SFA can trace the pathways of a specific substance or group of substances from Analysis (SFA) origin to destination, identifying where they assemble (Baccini \& Brunner, 2012). Most SFAs of the most broadly studied substance were conducted at national level, such as copper, zinc, cadmium, chromium, or a combination of phosphorous \& nitrogen (Yuan et al., 2011).

Emergy EA regards all systems as networks of energy flows and employs energy

Analysis (EA) equivalents or emergy (embodied energy) through using a same unit of measurement (the "solar emjoule") (Lei et al., 2016; Zhang et al., 2011). Embodied energy is the total energy required to produce any good or service, considered as if that energy was incorporated ("embodied") in the product itself from the original solar energy (Lei et al., 2016). Benefit from the same unit "solar emjoule", EA enables us to make comparisons between different flows for all fluxes of materials, energy \& money through a system (Zhang et al., 2011) and allot values to natural systems' environmental efforts \& investment to contribute to the economy (Sun et al., 2016). However, there is one drawback of this method: suitable energy transition rates must be ascertained for all flow and currently the approaches for evaluating wastes have not been unified (Zhang et al., 2013).

\begin{tabular}{ll}
\hline $\begin{array}{l}\text { Input- } \\
\text { Output }\end{array}$ & $\begin{array}{l}\text { I/O A evaluates the material fluxes between sector in an economy by tracking } \\
\text { product \& sector-specific resource flows (Musango \& Robbinson, 2017). The } \\
\text { environmental input-output tables aid to deliver a better understanding of the } \\
\text { actors in UM process, but it was argued that the results generated by I/O A are } \\
\text { (I/O A) } \\
\text { still approximate and imprecise due to limited data availability of energy \& } \\
\text { materials flows (which must be accounted for using economic capital matrices) } \\
\text { (Zhang et al., 2013). }\end{array}$ \\
\hline Ecological & EFA was initially served as a sustainability indicator of a human economy on \\
Footprint & $\begin{array}{l}\text { account of the carrying capacity of the earth and it can transform populations' } \\
\text { resources consumption into an individual indicator of how much land area is }\end{array}$ \\
Analysis & needed to sustain that population perpetually (Musango \& Robbinson, 2017). \\
(EFA) & EFA as an integrated indicator of resource \& land use, is also used for assessing \\
& UM flows which fills the gap between UMA and UM control \& planning \\
\hline
\end{tabular}


(Dakhia \& Berezowska-Azzag, 2010). EFAs are always used as a public awareness tool to communicate population or individual overconsumption patterns (Brunner, 2001). However, the selection criteria for the ecological supply area have not been unified, and EFA depends on insufficient description of the resources derived from the nature $\&$ the wastes eliminated by the natural system. Hence the magnitude \& significance of human impacts are underestimated (Zhang et al., 2013).

\begin{tabular}{ll}
\hline Life & LCA offers a "cradle-to-grave" examination of material flows embedded \\
Cycle & within products \& process to determine their broader impacts, mostly ideal for \\
assessing indirect flow associated with raw material \& products with a lower & degree of processing (Musango \& Robbinson, 2017). LCA is the most \\
(LCA) & (Bewerful UM tool for policy-related decision making as is well-known \\
& $\begin{array}{l}\text { There are three main types of simulation methods for UM studies, respectively, } \\
\text { they are system dynamics, agent-based modelling and discrete event. For } \\
\text { system dynamics, it combines qualitative \& quantitative analysis and is based } \\
\text { on relationship structure which allows models to work effectively even in } \\
\text { data-scarce environments. There is a drawback of system dynamics methods, } \\
\text { that is, decision rules used to build the model are not obtained from experiential } \\
\text { data, but from subjective perceptions of the modeller or stakeholders (Musango } \\
\text { \& Robbinson, 2017). }\end{array}$ \\
\hline $\begin{array}{l}\text { Not all the UM assessments employed only one method, some UMA integrated } \\
\text { multiple methods or extended conventional methods to include social welfare } \\
\text { indicators or rearranged the scope of inquiry to afford specific environmental } \\
\text { or sustainability indicators (Musango \& Robbinson, 2017). }\end{array}$
\end{tabular}

\subsection{Distribution of Global UM Studies}

According to the study of Musango \& Robinson (2017), the numbers of UM studies have increased dramatically in recent years especially after the year of 2000. During the period between 1974 and 2000, the total annual published UM studies were less than five. After a slight decrease from 2003 to 2005, the numbers of UM studies kept going up and reached its first peak at 16 in 2009. In 2016, there were $26 \mathrm{UM}$ articles published in total. For the variation of different urban metabolism assessments (UMA) applied in those studies, accounting methods are the most popular approach in academia as it's been used in UM studies since 1974 and it has been the only dominant approach until ecological footprint analysis (EFA) was invented and employed for UM studies in 2000. After 2000, both the numbers of UM studies and variations of UMA has been increasing continuously, which implies that the rising trends of UMA and UM have gained lots of research interests from the academia and government in recent years. It is noteworthy that the share of hybrid approaches has increased rapidly since 2012, suggesting that a combination of multiple methods to assess urban metabolism have more potential with its multiple merits inherited from other approaches.

On the other hand, the geographical distribution of UM studies in the world is uneven, which implies the biased attentions and unbalanced degree of importance that different countries have attached to the field of UM studies. Specifically, most UM studies concentrated in Europe, North America \& China while South America, Africa \& South Asia need more practice of UM studies used (Musango \& Robinson, 2017). It can be argued that the concept and theory of UM are quite solid, but the implementation and popularization of UM are so far restricted and confined by various limitations and constraints. This reveals two major key issues of the current status of UM practices: political boundaries for implementing UM and lack of a unified UMA. There is a suggestion that applying a common UMA on all major cities especially megacities around the world will make it much easier to compare different cities and develop a better understanding of urban development patterns and their impacts. The next section will explore the applications of urban metabolism and its future directions in detail. 
Table 3. Key reviewed UMA literature

\begin{tabular}{lll}
\hline Literature & Location & UM Methods \\
\hline Han et la. (2018). Urban metabolism of megacities: A & 4 cities around the & Multi-Scale Integrated \\
comparative analysis of Shanghai, Tokyo, London and & world: Shanghai, & Analysis of societal and \\
Paris to inform low carbon and sustainable development & Tokyo, London and & $\begin{array}{l}\text { Ecosystem Metabolism } \\
\text { pathways. Energy, 155, 887-898 }\end{array}$ \\
(MuSIASEM) & Paris
\end{tabular}

\begin{tabular}{|c|c|c|}
\hline $\begin{array}{l}\text { Lei et al. (2016). Mass, energy, and energy analysis of the } \\
\text { metabolism of Macao. Journal of Cleaner Production, } \\
114,160-170 .\end{array}$ & Macao, China & $\begin{array}{l}\text { Mass Energy \& Emergy } \\
\text { Analysis (MEEA) }\end{array}$ \\
\hline $\begin{array}{l}\text { Sun et al. (2016). Uncovering driving forces on urban } \\
\text { metabolism-A case of Shenyang. Journal of Cleaner } \\
\text { Production, } 114,171-179 \text {. }\end{array}$ & Shenyang, China & $\begin{array}{l}\text { Emergy Analysis (EA) } \\
\text { with Logarithmic Mean } \\
\text { Divisia Index (LMDI) }\end{array}$ \\
\hline
\end{tabular}

Rosado et al. (2016). Urban metabolism profiles. An 3 cities, Sweden: Material Flow Analysis empirical analysis of the material flow characteristics of three metropolitan areas in Sweden. Journal of Cleaner Production, 126, 206-217. Stockholm, Malmo, (MFA) Gothenburg

Zhang, Y., Yang, Z., Liu, G., \& Yu, X. (2011). Emergy Beijing, China analysis of the urban metabolism of Beijing. Ecological Modelling, 222(14), 2377-2384.

\begin{tabular}{|c|c|c|}
\hline $\begin{array}{l}\text { Currie et al. (2017). Urban metabolism: A review with } \\
\text { reference to Cape Town. Cities, 70, 91-110. }\end{array}$ & $\begin{array}{l}\text { Cape Town, South } \\
\text { Africa }\end{array}$ & MFA \& mass balance \\
\hline $\begin{array}{l}\text { Sahely et al. (2003). Estimating the urban metabolism of } \\
\text { Canadian cities: Greater Toronto Area case study. } \\
\text { Canadian Journal of Civil Engineering, } 30(2), 468 \text {. }\end{array}$ & Toronto, Canada & $\begin{array}{l}\text { MFA \& Input Output } \\
\text { Analysis (I/O A) }\end{array}$ \\
\hline $\begin{array}{l}\text { Thomson, G., \& Newman, P. (2018). Urban fabrics and } \\
\text { urban metabolism - from sustainable to regenerative } \\
\text { cities. Resources, Conservation and Recycling, 132, } \\
218-229 \text {. }\end{array}$ & Perth, Australia & $\mathrm{I} / \mathrm{O} \mathrm{A}$ \\
\hline $\begin{array}{l}\text { García-Guaita et al. (2018). Integrating Urban } \\
\text { Metabolism, Material Flow Analysis and Life Cycle } \\
\text { Assessment in the environmental evaluation of Santiago } \\
\text { de Compostela. Sustainable Cities and Society, 40, } \\
\text { 569-580. }\end{array}$ & $\begin{array}{l}\text { Santiago de } \\
\text { Compostela, Spain }\end{array}$ & $\begin{array}{l}\text { MFA \& Life Cycle } \\
\text { Assessment (LCA) }\end{array}$ \\
\hline $\begin{array}{l}\text { Conke, L. S., \& Ferreira, T. L. (2015). Urban metabolism: } \\
\text { Measuring the city's contribution to sustainable } \\
\text { development. Environmental Pollution, 202, 146-152. }\end{array}$ & Curitiba, Brazil & $\begin{array}{l}\text { Abbreviated } \\
\text { Metabolism } \\
\text { (AUMF) }\end{array}$ \\
\hline $\begin{array}{l}\text { Moore et al. (2013). An urban metabolism and ecological } \\
\text { footprint assessment of Metro Vancouver. Journal of } \\
\text { Environmental Management, 124, 51-61. }\end{array}$ & $\begin{array}{l}\text { Metro } \\
\text { Canada }\end{array}$ & $\begin{array}{l}\text { Ecological } \quad \text { Footprint } \\
\text { Analysis } \quad(\text { EFA }) \& \\
\text { residential consumption }\end{array}$ \\
\hline
\end{tabular}

\section{Applications of UM and Future Directions}

\subsection{Urban Typologies, Systems \& Sustainability}

\subsubsection{Understanding Urban Systems' Dynamics}

One of the most important applications of the UM concept is to enhance understanding of urban systems and their dynamics. Cities are among the most heterotrophic ecosystems in the biosphere (Odum, 1994; Lei et al., 2016), they are ever-mutating open systems which depend more intensively on ecosystems beyond the city boundaries (i.e. their hinterlands) for material, resources and energy (Rees \& Wackernagel, 1996; Melosi, 2009; Baccini \& Brunner, 2012; Currie et al., 2017). Urban Metabolism Assessment (UMA) is a powerful tool for understanding urban ecosystems as it aids to understand the correlation \& connection between resource consumption and the 
products production, associated by-products and waste disposal (Lei et al., 2016). Musango \& Robbinson (2017) claims that assessing UM is essential to provide the baseline understanding of urban settings and potential levers. Moreover, on the report of Céspedes Restrepo \& Morales-Pinzón (2018), UM could be applied for discerning the natural and anthropic availability of resources and their use in order to retain the current condition of the ecosystem and the environment. Indeed, another application of UM pointed by Céspedes Restrepo \& Morales-Pinzón (2018) is to evaluate and estimate the environmental impacts triggered by urban systems.

Furthermore, Cui (2018) claims that studies on food supply \& consumption would reinforce urban metabolic functions and help resolve the pollution issue simultaneously as the nutrient flow from urban consumption is the main sources of the ecosystem pollution. In addition, Kennedy et al. (2011) also state that UM can acquire crucial $\&$ critical information for quantifying urban greenhouse gas (GHGs) emissions.

\subsubsection{Establishing a Circular Economy \& Circular UM}

Cities with higher dependency on external resource, material \& energy have lower resilience to secure material supplies \& maintain regular service functions. Rosando et al. (2016) proposed two key strategies for improving cities' resilience, respectively, they are reducing dependence on fossil fuels and increasing availability of domestically produced biomass. It's highlighted that closing the linear loops and establishing a circular economy as well as circular UM is the key to increase \& intensify cities' resilience. For instance, material recycling is recognized to have high potential to minimize cities' dependence on both exterior \& non-renewable resources, so it could be a principal focus for urban development \& policy making (Rosando et al., 2016).

In order to transfer the current resource efficiency from a linear to a circular or cyclical perspective, it's possible that UM assessment could solve the obstacles during this transformation (Musango \& Robbinson, 2017). Moreover, Cui (2018) also claims that a concrete economy in the UM context towards sustainable development could be accomplished via tackling hurdles in urban development implementation for a circular economy. As stated, UM studies could be utilized as a tool to resolve sustainable development issues and requirements to attain dematerialization, decarbonization and the circular material loops (Barles, 2010).

\subsubsection{Resource Efficiency and/or Resource Efficiency Intervention}

A more confined application is in analysis and development of resource efficiency. Newman (1999) argued that the laws of thermodynamics implicit that a biological system's waste outputs depend on its resource inputs. Therefore, it is suggested that reducing resource inputs is the optimal method to decrease the metabolism flow effectually (Newman, 1999). UM can inspect implications of the energy \& material needs of cities on their hinterlands and the whole biosphere as well as provide the basis for interpreting urban biogeochemical process \& social operational interactions (Barles, 2010). Hence, UMA is regarded as a guiding framework for municipal-level resource efficiency transition to engage and initiate resource flows \& explore feasible resource efficiency approaches (Musango \& Robbinson, 2017).

\subsubsection{Assisting Urban Transition Towards Sustainable Development}

Last but not least, UM studies can also be used to assess cities' sustainability or to be developed as sustainability indicators with respect to resource consumption \& waste generation (Barles, 2010; Musango \& Robinson, 2017; Cui, 2018). Maclaren (1996) delineated several criteria for good sustainability indicators:

a) Scientifically valid (based on principles of conservation of energy \& mass)

b) Representative, responsive, relevant to urban planners and residents

c) Based on data that is comparable over time, comprehensible and clear (Kennedy et al., 2011)

Kennedy et al. (2011) argued that the UM variables substantially meet the criteria proposed by Maclaren, meanwhile, those variables involve relevant information about energy efficiency, material cycling, waste management, and urban infrastructure. Furthermore, Cui (2018) states that a city's contribution to sustainability can be evaluated by UM through the following key aspects, respectively, they are time, cycles, simplicity, and livability. The time aspect represents evaluating the influence of UM on the ecosystems over time (Cui, 2018). The biogeochemical cycle of metabolic elements like $\mathrm{H}_{2} \mathrm{O}, \mathrm{C}, \mathrm{N}, \mathrm{P}$ and air pollution emissions are covered as well ${ }^{67}$. He claims that the influences of UM elements on sustainability can be simplified via modelling and translating for policy makers $\&$ urban planner while livability includes the socioeconomic aspects of sustainability such as use and reuse resources for social well-being (Cui, 2018). In addition, as stated by Kennedy et al. (2014), UMA can help and support urban planners \& environmental managers to enhance cities' resource efficiency, minimize negative environmental impacts of UM fluxes and isolate concerned problem areas. Overall, there is no doubt that UMA is considered as an essential \& standard analytical approach in programs aiming to achieve sustainable 
urban development (SUD) (Kennedy et al., 2014).

\subsection{Challenges for UM Studies \& Implementation}

Basically, there are two major challenges for assessing UM or UMAs: lack of standardization and data deficiency at city-level. Besides them, there are various other challenges for UM studies \& implementation. In a systematic review of urban sustainability (US) assessment literature, Cohen (2017) argued that it's very challenging to select sufficient and appropriate indicators from thousands of types to create a unified standard for US assessment applied to all cities. Although Urban Metabolism (UM) hasn't developed a unified assessment approach, its applications also vary across different disciplines. UM is a multi-disciplinary field of study with high potentials \& bright prospects for sustainability, urban sustainability, sustainable development and sustainable urban development, but its implementation is quite restricted due to several limitations and constraints. For instance, there are only five of Cohen's 69 reviewed articles that used UM method for assessing US (Cohen, 2017).

On the other hand, Musango \& Robbinson (2017) argued that there are two key challenges of UM studies nowadays. One is to transition from a linear perspective to a circular perspective (See above Section 3.2.2), in which wastes are utilized as a resource in the urban environment. The other is the limited practical implementation of UM although the UM concept is currently embraced in academia (theoretically) and politically (Musango \& Robbinson, 2017).

As mentioned before, no consensus exists about the best choice of methods for estimating complex systems' sustainability such as urban systems (Musango \& Robbinson, 2017). Most of the past UMAs have been done in different ways, even though UMAs with the same method were done in different styles. Moreover, Musango \& Robbinson (2017) argued that both instructions for sustainable UM development and the implementation of the UM concept in policy development \& spatial planning are very limited \& restricted. Most UMAs have been undertaken at the national or regional level because of the greater availability of material flow data, or trade proxies (Musango \& Robbinson, 2017). As a consequence, most UMAs utilized top-down approaches rather than bottom-up approaches which make the results of UMA less accurate and less comparable.

\subsection{Future Directions of UM Studies}

There are several future directions for UM studies such as analysis of UM in the context of climate change, considering spatial \& temporal issues (Musango \& Robbinson, 2017), understanding the role of social factors in urban dynamics (Céspedes Restrepo \& Morales-Pinzón, 2018) as well as the evolution \& dynamics of urban dweller's activities (Beloin-Saint-Pierre et al., 2017). For the issue of lack of standardized UMA, it is suggested that future work may include undertaking a basic UMA for all cities, to promote transdisciplinary approaches, standardize collected data forms (Musango \& Robbinson, 2017), and develop general UM models (Céspedes Restrepo \& Morales-Pinzón, 2018). This will enable comparability between cities, for baseline setting, comparison \& progress reporting (Musango \& Robbinson, 2017). Furthermore, Thomason \& Newman (2018) also suggested that urban metabolism (UM) could be improved through covering regenerative design, introducing biophilic urbanism \& optimizing Urban Fabrics (UF) (walking UF, transit UF, automobile UF).

The previous sections have examined the concepts \& theories, applications \& research methodologies of UM and challenges of its implementation. To enrich the consideration of UM in previous and later sections, the paper now moves to urban sustainability (US), and to commentary on the developing debates about 'big data' and 'smart cities'-two concepts that bear relationship to UM studies.

\section{From Urban Sustainability (US) to Global Sustainability (GS)}

\subsection{Sustainability \& Sustainable Development (SD)}

The term 'sustainability' originates from various disciplines including social justice, conservationism, internationalism and several other past movements with abundant historical backgrounds, which had merged together and consolidated in a bid to realize 'sustainable development (SD)' (University of Alberta Office of Sustainability, n.d.). SD is defined as "development that meets the needs of the present without compromising the ability of future generations to meet their own needs" in the report Our Common Future released on the "Brundtland Commission" in 1987 (Troy, 2013; UAOS, n.d.).

It's often argued that applying the concept of sustainability in practice can make substantial and remarkable impacts in the long run, no matter how significant the scale of these practices is (UAOS, n.d.). SD has the potential to assure ecological health, social equity and economic growth together at the same time ${ }^{67}$, which implies that SD is a powerful approach for promoting and promising long-lasting prosperity of the future. Furthermore, Cohen (2017), in his review of US literature, recognized sustainability as "an endeavor to bring society within the Earth's planetary boundaries while lifting the global population above a basic standard of living." 
The concept of Triple Bottom Line (TBL) was firstly introduced by John Elkington in 1994 for business and accounting frameworks, which refers to people, planet and profit (Investopedia, 2018; Sustainability Illustrated, 2014). This concept has evolved into social, environmental and economic dimensions, which is also known as the three pillars of sustainability or triple bottom line (TBL) (Sustainability Illustrated, 2014; Sierra Forest Legacy, 2012). And besides conventional TBL of sustainability, some US studies added extra dimensions to sustainability such as institutional to define good governance setting, integrated dimension which serves as an interface of two traditional pillars like socio-economic, social-environmental, and environmental-economic (Cohen, 2017). But TBL still is considered as the fundamental tool for defining sustainability.

Moreover, there are interconnected and interdependent benefits among three pillars or TBL of sustainability and such different kinds of relationships can be generally divided into two types: weak sustainability (WS) and strong sustainability (SS). As is can be seen in Figure $2 \& 3$, the perspective of SS highlights the principal role of environment as the fundamental basis for social \& economic sustainability and also the view that the economy is the most dependent dimension of sustainability which totally relies on society and the environment.

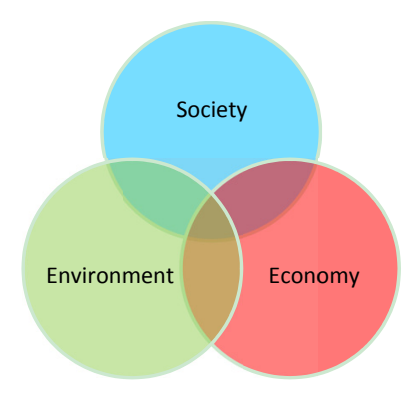

Figure 2. Triple bottom line: weak sustainability (Adapted from Sierra Forest Legacy, 2012)

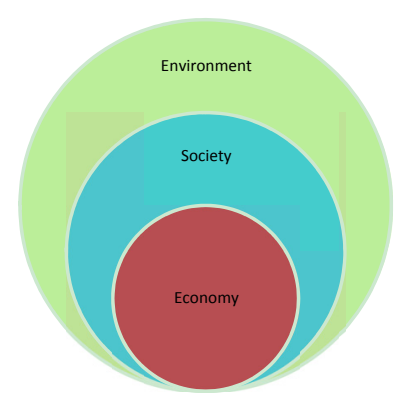

Figure 3. Triple bottom line: strong sustainability (Sierra Forest Legacy, 2012)

According to Pelenc, Ballect \& Dedeurwaerdere (2015), there is a basic debate in relation to SD on which is the right choice: weak sustainability (WS) or strong sustainability (SS)? WS presupposes the full substitutability of natural capital while SS presents that the substitutability of natural capital should be strictly limited as natural capitals furnish critical elements for living and well-being of our human beings (Pelenc et al., 2015). Brand (2009) argued that these "critical" elements can be conceptualized as ecosystems service from natural capital which emphasizes the importance of keeping natural systems' ecological functioning for preserving natural capitals. However, it's hard to evaluate whether an ecosystem service is critical or not due to the uncertainties and/or unknowns about ecosystems \& ecosystem services ${ }^{81}$. This would suggest that public participation and stakeholder analysis is needed to define the criticality of natural capital (Van den Hove, 2000; De Groot et al., 2003; Dedeurwaerdere, 2013; Pelence et al., 2015).

Generally, there are three main reasons to support the review that there is no full substitutability of natural capital and adopting strong sustainability (SS) is an appropriate choice. Firstly, Pelenc et al. (2015) claimed that "manufactural capital is reproducible, and its destruction is merely irreversible whereas the consumption of natural capital is usually irreversible." For example, species extinction is irreversible resulting in biodiversity loss which has become one of the major global challenges for now. Secondly, Ekins et al. (2013) pointed out that 
manufactural capital requires natural capital for its production; thus, it is impossible to fully substitute the biophysical structures of natural capital. Thirdly, there is an intergenerational environmental justice issue relating to weak sustainability (WS): "an increase of future consumption is not an appropriate substitute for losses of natural capitals" ${ }^{81}$. For instance, we the present generation have no right to limit future generations' freedom to choose clean air rather than more goods \& services by asking future generations to live in the polluted air in exchange for a better manufactural capacity (Pelenc et al., 2015). Hence, it seems suggest that strong sustainability (SS) would be the right choice over weak sustainability (WS) in assisting future directions of sustainable development. Table 4 illustrates the main difference between WS \& SS (Pelenc et al., 2015).

Table 4. Strong sustainability vs. weak sustainability (Adapted from Pelenc et al., 2015)

\begin{tabular}{|c|c|c|}
\hline & Strong sustainability & Weak sustainability \\
\hline Key idea & $\begin{array}{l}\text { The substitutability of natural capital } \\
\text { by other types of capital is severely } \\
\text { limited }\end{array}$ & $\begin{array}{l}\text { Natural capital and other types of } \\
\text { capitals (manufactured etc.) are } \\
\text { perfectly substitutable }\end{array}$ \\
\hline Consequence & $\begin{array}{l}\text { Certain human actions can entail } \\
\text { irreversible consequences }\end{array}$ & $\begin{array}{lrr}\text { Technological innovation } & \text { and } \\
\text { monetary compensation } & \text { for } \\
\text { environmental degradation } & \end{array}$ \\
\hline Sustainability issue & $\begin{array}{l}\text { Conserving the irreplaceable 'stocks' } \\
\text { of critical natural capital for the sake of } \\
\text { future generation }\end{array}$ & $\begin{array}{l}\text { The total value of the aggregate stock } \\
\text { of capital should be at least } \\
\text { maintained or ideally increased for } \\
\text { future generation }\end{array}$ \\
\hline Key concept & Critical natural capital & Optimal allocation of scare resources \\
\hline $\begin{array}{l}\text { Definition of thresholds } \\
\text { and environmental } \\
\text { norms }\end{array}$ & $\begin{array}{l}\text { Scientific knowledge as input for } \\
\text { public deliberation } \\
\text { rationality) }\end{array}$ & $\begin{array}{l}\text { Technic/scientific approach for } \\
\text { determining thresholds and norms } \\
\text { (instrumental rationality) }\end{array}$ \\
\hline
\end{tabular}

\subsection{The Role of US in Achieving SD and GS}

Definitional issues are common in any discussion or application of sustainability principles. According to Hamman, Anquetin \& Monicolle (2017), there is eventually no individual or completely predominant definition of 'sustainable city' or 'sustainability'. Since 1987, when the definition of sustainable development (SD) was proposed by the "Brundtland Commission" (UAOS, 2013), Zaccai (2012) argued that the equivocality of the Brundtland Report or the Rio Conference have still not been clarified. In a comparative review of the French- and English- literature, Hamman et al. (2017) analysed and discussed the contemporary meaning of the 'sustainable city' \& the model of 'sustainable city'. In order to explore and develop the model of 'sustainable city', Hajek et al. suggested to reconsider the relationships between society \& nature and nature in the city in the light of ecological justice \& bottom-up initiatives and Choné et al. suggested to consider daily life like housing and food as well (Hamman et al., 2017).

However, Cohen (2017) argued that a city is sustainable if it $\&$ its hinterlands are designed and managed to not put excess environmental pressures over primal boundaries and limits while offering livelihood \& equity supports to all resident. Beatley also claimed that constructing a "green" city is same as achieving sustainability and the building of green cities \& eco-cities has becoming a first step of sustainable development (SD) in many countries (UN, 2013). The UN (2013) proposed four dimensions of urban sustainability (US), including social development, economic development, environmental management, and urban governance. As illustrated in Figure 4, achieving sustainability of cities or US can be recognized as implementing the consolidation of four pillars. 


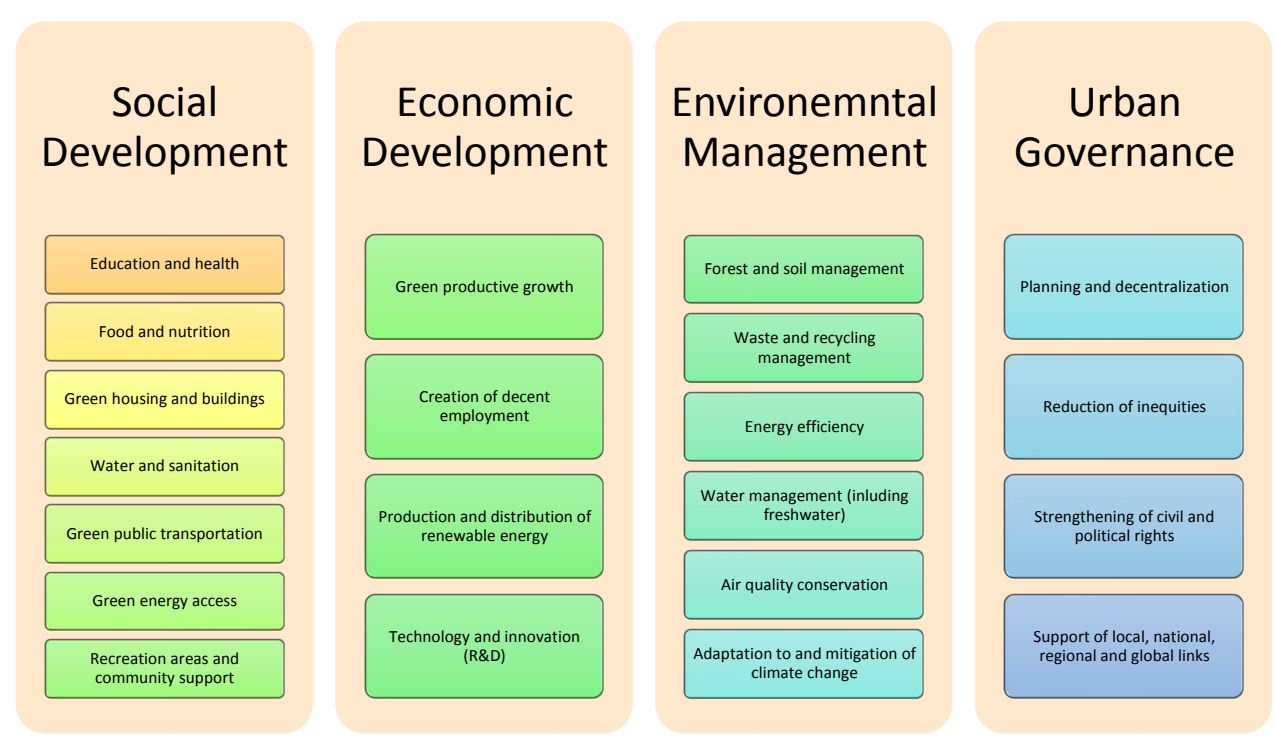

Figure 4. Pillars for Achieving Urban Sustainability (UN, 2013)

Cities play an important and prominent role in achieving global sustainability as the city is the center of human habitat and social activity (See Section 2.1) and an urban paradigm shift for sustainable and territorial development is the key to achieve sustainable development (and/or Global Sustainability) (Thomason \& Newman, 2018).

Furthermore, Zhang et al. (2011) stated that urban metabolism (UM) concept is closely connected to sustainable development (SD) as both UM \& SD focus on the consistent ecosystem services that support human beings by offering material and services. Therefore, assessing the environmental impacts of cities' metabolism (or UM) and modelling their behaviors are becoming essential to achieve SD as well as urban sustainability (García-Guaita et al., 2018).

\subsection{Connecting UM \& US}

A review by Cui (2018), found that sustainability and UM are closely connected and claimed that the 'metabolism' metaphor reinforces the relationship between the social well-being \& prevent biodiversity loss, resource scarcity and environmental degradation. Additionally, UM studies are perceived as an essential element for accomplishing urban sustainability (US) in future cities by "which the city is reinserted in the nature and nature in the city" (Céspedes Restrepo \& Morales-Pinzón, 2018; Díaz Álvarez, 2014). According to Céspedes Restrepo \& Morales-Pinzón (2018), it is suggested by the dominating urban ecology approach about UM that US relies on the resource efficiency and the gradual elimination of linear metabolic flows towards a circular UM (Acselrad, 1999; Yang et al., 2014; See Section 3.2.2). From this point of view, Céspedes Restrepo \& Morales-Pinzón (2018) argued that two critical features of unsustainable urban systems are ongoing dependence on materials \& energy importation and massive exportation of wastes to the ecosystem. Their perspective about unsustainable cities reveals the underlying correlation between circular metabolism \& US as well as the importance of UM studies in addressing the challenges of achieving urban sustainability. Videlicet, urban sustainability (US) can be considered as the blueprint of ultimate outcome of circular UM while approaches \& practices towards circular UM can foster sustainable urban development (SUD) and/or urban sustainability (US).

\subsection{Environmental Justice Issues of Urban Systems}

Regarding to the three pillars of sustainability (See Figure $2 \& 3$ ) and four pillars of urban sustainability (See Figure 4), environmental injustice is an unignorably critical issue embraced inn those pillars, and it is one of the major challenging hurdles in achieving urban sustainability as well as planetary sustainability for all.

Generally, environmental injustice is recognized as a nexus of economic injustice, social injustice and an unjust incidence of environmental quality (Gelobter, 1994), and Corburn (2017) defined environmental justice as " $a$ framework for understanding and acting to address the disproportionate, unfair, and unequal environmental burdens that the poor and people of color populations experience due to exposures of toxic harms and receiving less legal and other protections that white and well-off communities." 
For instance, the costs of environmental protection are regressively distributed since most common methods of pollution control (i.e. taxes, subsides and etc.) are functionally equivalent to a consumption tax. Gelobter (1994) argued that the rich spend much less proportionally of their earnings than the poor, thus increasing consumption tax as environmental protection approaches always hit the poor most. He identified three interconnected key urban environmental justice problems, respectively, they are health-related problems, space-related problems, and structural/economic problems.

Environmental justice issues can be seen as a result or side effect of various global major challenges including environmental degradation, social inequity, poverty and pollution. It is obvious that such kind of issues cannot be solved by a single solution, an integrated comprehensive approach is needed to mitigate and even resolve them all at once. This implies the importance, necessity and potentials of an UM approach in building towards sustainability at all scales.

In order to deal with the difficulties and challenges involved in the process of achieving sustainable development (SD), not only the political context and theoretical basis are needed, but technological supports are also essential as they act as a platform for further practices. Meanwhile, the Age of Big Data's potential keeps growing and the concept of Smart Cities (SC) continues gaining more and more attention in urban planning and development in recent years because of promises to provide numerous opportunities to promote SD and achieve urban sustainability (US).

The next section will discuss the relationship between smart cities \& sustainable development as well as the politics of data.

\section{The Role of Big Data in Smart Cities (SC)}

\subsection{Smart Cities and/or Sustainable Cities?}

\subsubsection{The Concept of Smart Cities and Its Practices}

The concept of 'smart cities' has become one of the most popular and critical research topics and policy-making focuses for both developed and developing countries globally (Yigticanlar \& Kamruzzaman, 2018). It can be considered as an inheritor of information city, digital city, intelligent cities and sustainable city; which goes one better as smart cities (SC) make capital of information \& communication technology (ICT) in support of systems \& services for urban residents (Trindade et al., 2017). Like the foundation of UM concept, there is no consensus in the literature on the definition of a smart city (Angelidou, 2014; Hortz, 2016; Trindade et al., 2017). For instance, Angelidou (2014) defined smart cities (SC) as a conceptual model where urban development is accomplished via utilizing human, collective and technological capital. While as stated by Vanolo (2013), smart city is an efficiently, technologically advanced, green and socially inclusive city. Generally, it is perceived that SC makes the most of ICT widely to improve cities' competitiveness and optimize their operations \& services (Trindade et al., 2017). This perception implies the potentials of SC for enhancing cities' UM with the benefits \& contributions of ICT. Furthermore, several authors have identified six essential elements of SC as follows: smart economy, smart mobility, smart environment, smart people, smart living and smart governance (Lazaroiu \& Roscia, 2012; Lee et al., 2014; Jong et al., 2015; as cited in Trindade et al., 2017).

In addition, as believed by Yigicanlar and Kamruzzaman, the increasing attentions of the environmental impacts of rapid development since 1970s have resulted in the foundation \& evolution of concepts like sustainability, sustainable urban development (SUD) and smart cities (SC) and etc. (Trindade et al., 2017). Yigitcanlar (2015) also argued that SC focuses on producing vanguard high technologies for resolving ecological, social, and environmental management challenges. Nevertheless, there is a controversial debate about whether SC is just a buzz phrase that has outlived its utility \& versatility or a promising pathway of sustainable future \& US (Trindade et al., 2017). Trindade et al. (2017) argued that the answer to whether the Smart City concept and its practice can promote urban sustainability (US) is still unclear, and more studies is needed to end this controversial debate. This essay will discuss the correlation between UM, smart cities \& urban sustainability and try to examine if promoting smart cities can foster $\&$ further urban sustainability in latter sections.

\subsubsection{Connections \& Differences Between Smart Cities and Sustainable Cities}

In a systematic literature review of smart cities (SC) and sustainable development (SD), Trindade et al. (2017) examined both terms and focused on the SD of SC. They argued that 'smart city' is regarded as a vision, manifesto or promise for the sake of establishing the 21th century's sustainable \& ideal city form while sustainable cities devote to both sustainable development (SD) \& sustainable urban development (SUD) (Trindade et al., 2017). On the authority of World Commission on Environment and Development (WCED) (1987), SUD can be defined as " $a$ process of change in which resource exploitation, investment direction, technological development and 
institutional change are consistent with present and future needs". Moreover, Zhao (2011) and Goonetilleke et al. (2014) claimed that the spreading of the sustainability ideology has engraved a deep mark on urban planning \& development. This promoted the growing of SUD's concept, research and practice around the world over the past decade. In accordance with Conroy \& Berke (2004), embracing sustainable urban development (SUD) rules \& paradigms in urban planning and strategical policymaking especially at local level is essential to approach Urban Sustainability (US) and generate sustainable outcomes which benefits building ecological sustainability-an essential component of Smart Cities. Thus, the strong supplementary correlation between SC and sustainable development (SD) (and/or SUD) is indubitable. As stated by Ahvenniemi et al. (2017), "a city that is not sustainable is not really smart". This point of view connotes the underlying relationship between smart cities (SC) and urban sustainability (US) (and/or sustainable city).

Furthermore, it can be argued that urban sustainability (US) is a sufficient condition of sustainable urban development (SUD). There are four dimensions or pillars of US: social development, economic development, environmental management, and urban governance (UN, 2013; See Section 6.2) which corresponding the quadruple bottom line of SUD proposed by Yigitcanlar \& Teriman (2015): societal, economic, environmental, and governance. Besides, sustainable urban development (SUD) is seen as a panacea for the current global major challenges and negative impacts of The Anthropocene Era which leads to the worldwide prevailing of smart cities (SC) research and practice (Yigticanlar \& Kamruzzaman, 2018). Since SUD is the underlying basis of SC and urban sustainability (US) can be achieved through SUD, US can be seen as the intangible baseline of smart cities while advanced technologies of smart cities can be considered as a technological base for achieving future urban sustainability.

\subsection{The Age of Big Data \& the Politics of Data}

As we know, a smart city relies on Information and Communication Technology (ICT) services to improve its performance and competitiveness for urban residents in favour of boosting UM at the same time (See Section 7.1.1). ICT services of smart cities (SC) generates massive amount of data, which has been raising the concerns of privacy issues and discussions over the politics of data (Van Zoonen, 2016). Typical questions including who owns the data who has legitimate access, which data can be open data? All these issues regarding to data openness, data activism, data justice and data ethics are about the politics of data. However, studies and research for the politics of city data is very limited, as is the discussion about the negative social influences of massive data collection (Kitchin, 2014; as cited in Van Zoonen, 2016). Moreover, Kitchin (2014) argued that SC infrastructures and systems that increase the level of smart governance and efficiency could probably violate urban residents' privacy rights, confidentiality, and freedom of expression. Therefore, Van Zoonen (2016) highlighted that it's critical to be aware of people's concerns of privacy issues in the process of building smart cities (SC) for keeping their acceptance \& participation. Otherwise, any kind of SC practices will be questioned and abandoned without such awareness (Van Zoonen, 2016). Like SC, UM approaches also experiences similar data politics issues, especially data shortage and limited access of data when assessing UM at regional level. For dealing with this problem, a bottom-up approach is recommended (See Section 5.2). In this Age of Big Data, researchers, urban planners and decision makers should pay more attention to the data politics issue and manage to find a comprehensive approach to resolve it, especially in the context of promoting the development $\&$ construction of smart cities. The next section will explore the chances \& challenges of building smart cities (SC) and look into the future.

\subsection{Opportunities, Challenges \& Future Perspectives of SC}

Even though the current practices of SC are very limited and deficient, it's no hard to foresee plenty of promising opportunities in practicing \& building smart cities (SC). Besides the efficiency, effectiveness and convenience powered and provided by advanced ICT services in smart cities, there are various other opportunities involved in developing smart cities. While smart urban technologies improve a smart city's operations \& services, the efficiencies of its UM are also increased at the same time (See Section 7.1.1). In other words, smart cities provide opportunities for boosting cities' UM functions with the aid of technological advantages. On the other hand, it can be argued that developing SC and achieving sustainable urban development (SUD) (and/or sustainable development) support and supplement each other (See Section 7.1.2). Since SUD is a prerequisite of urban sustainability (US), it can also be argued that smart cities (SC) provide opportunities for achieving US as well. Despite SC seem to a promising direction for future urban planning \& development, there are still some defects, limitations and difficulties with respect to SC practices.

There are various challenges and criticizes associated with building smart cities (SC). Firstly, as mentioned in the previous section (See Section 7.2), one of the major challenges of SC is the data politics issue. As claimed by 
Towns, issues about data ownership, privacy rights \& public perception have been the biggest difficulty or obstacle that stops cities from sharing \& integrating data in manners that aid more thorough and concrete analysis (Van Zoonen, 2016). Secondly, as believed by Kunzmann (2014), the main risk of SC is related to ultra-dependency of smart technologies. If city residents rely on smart cities (SC)'s ICT services too much, they will eventually lose the ability to live or even survive in cities without technologies, for instance, nowadays people can easily get lost in cities without GPS navigation services. Thirdly, Yigticanlar \& Kamruzzaman (2018) argued that SC projects consist of costly and large investments while the world's first smart city-Songdo (Korea) is still a project in development which hasn't deliver any actual material sustainable results; and Shwayri (2013) ascertained the negative environmental externalities induced by the process of building the Songdo smart city.

In order to tackle those obstacles, there is a long way to go. For the data politics issues, there is a need for more attention, response options and solutions. Furthermore, Van Zoonen (2016) proposed a privacy framework to identify possible sensitivities that people may have about smart cities (SC) data (See Figure 5). He argued that different smart urban technologies with different functions and their usage \& analysis of data are key factors influencing people's privacy concerns about SC (Van Zoonen, 2016). This framework could be used to identify specific privacy concerns and policy makers could develop a particular city policy on new developments not only for legal necessities but also for taking into account people's concerns (Van Zoonen, 2016). For example, the privacy issues associated with commercial, governmental and recreational use of drones. Furthermore, Taamallah et al. (2017) emphasized the importance of smart urban technologies in accomplishing comprehensive urban sustainability (US) rather than solely focusing on the concept of smart cities (SC). That is to say, promoting smart urban technologies is a critical part of SC practices and US cannot be approached without promoting both SC concept \& practice simultaneously. Furthermore, it is suggested that smart cities call for strategy \& leadership, policies \& plans that merge bottom-up initiatives at corporation or institution level with planned projects involving different stakeholders under a consistent prospect for the future urban ecosystems (Kominos, 2016; Yigticanlar \& Kamruzzaman, 2018). This point of view also reveals the hidden extensive links between SC \& UM, as urban ecosystems form key elements of UM and the success of SC practices depended on espousing ecosystem perspective of UM.

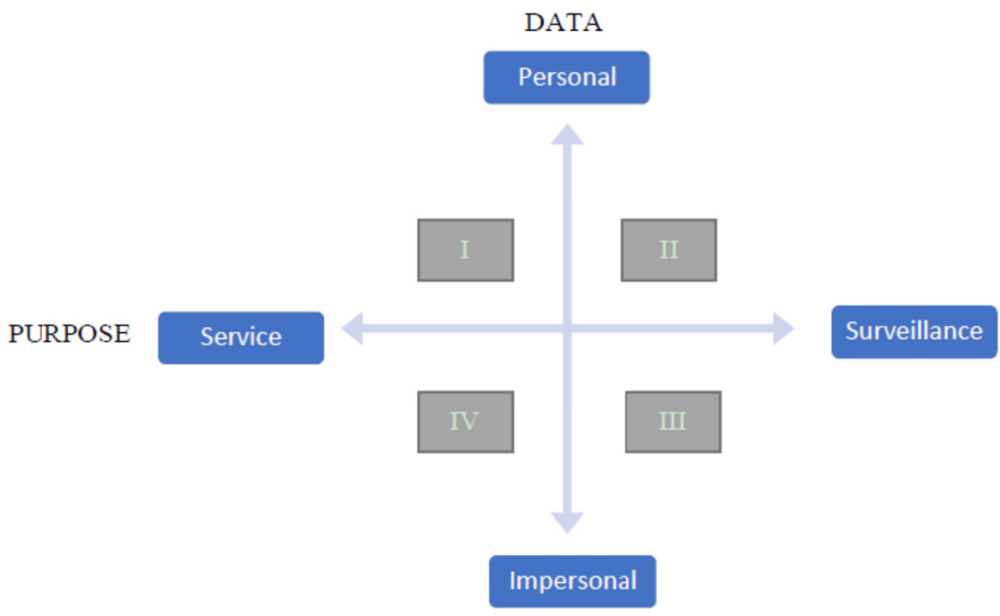

Figure 5. Smart city privacy challenges (Van Zoonen, 2016)

The previous sections examine UM, US and SC in details and their potentials to overcome current global major challenges, leading to the considerations about hidden linkages between them. The final sections of this paper attempt further synthesis of urban metabolism and related concepts.

\section{The Nexus among Urban Metabolism, Urban Sustainability and Smart Cities}

\subsection{The UM-US-SC Nexus}

The correlation between urban metabolism (UM) \& urban sustainability (US) and the critical role of UM in accomplishing sustainable development (SD) are well demonstrated (See Section 6.2), which calls for an urban paradigm shift in accordance with SD. While the linkages \& differences between smart cities (SC) \& SD (and/or urban sustainability) are explored (See Section 7.1.2). It's likely that there is an interactional nexus among UM, 
US and SC which can be proposed as "The UM-US-SC Nexus".

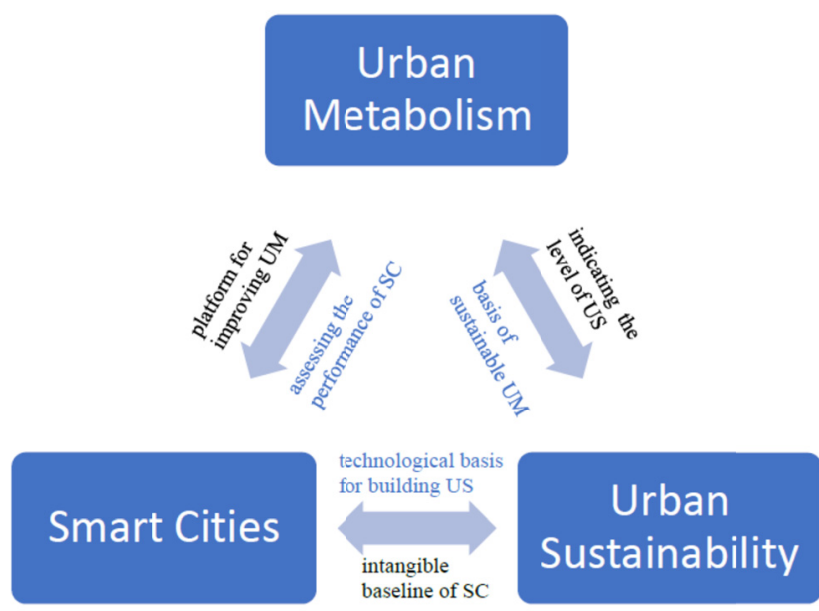

Figure 6. The UM-US-SC Nexus

In respect of urban planning \& environmental management towards sustainable development (SD), the relationship among urban metabolism (UM), urban sustainability (US) and smart cities (SC) could be proposed as "The UM-US-SC Nexus" (See Figure 6). First of all, both the level of US and the performance of SC can be assessed through UM or Urban Metabolism Assessments (UMA). In turn, when considering UM as an indicator for attributes of cities, it can be improved in the process of developing smart cities (SC) and achieving urban sustainability (US). Moreover, there is a mutually reinforcing relationship between SC \& US as they have some goals in common. Technologies for building smart cities also aid to solve obstacles in achieving US (and/or SD). Smart cities (SC) provides technological basis for future urban sustainability (US) while US is the intangible baseline of SC. In a word, each elements of this UM-US-SC Nexus can reinforce each other, and an integrated comprehensive approach based on the rationale of this UM-US-SC Nexus could resolve their boundaries and achieve all the goals at the same time. In addition, since urban metabolism (UM) plays two roles at once in this nexus (an indicator \& an assessment tool), this would suggest that UM is the most critical element in the UM-US-SC Nexus and it's essential to solve global major challenges \& promise a more sustainable future.

The above introduction to the UM-US-SC Nexus now leads to more detailed exploration of the underling interactions \& interconnections among US \& SC, US \& SD, and SD \& SC that will help to enrich the conceptualization of the UM-US-SC Nexus.

\subsection{The Role of UM in Environmental Management \& Urban Planning}

First of all, UM can be act as an environmental indicator in environmental management \& urban planning (EMUP). Assessing UM offers critical hints about urban systems' direct \& indirect environmental impacts as a result of their use of natural resources, such as Life Cycle Assessment (LCA), which is critical to evaluate \& compare the environmental impacts of different products and production process (ADB, 2014; Musango \& Robinson, 2017). By comparing quantitative urban metabolic indicators \& variables of different urban systems, UM can help identify the best practices (ADB, 2014). Additionally, initial indicators generated from Urban Metabolism Assessments (UMAs) could facilitate engagement with the urban decision-makers and environmental managers (See Section 3.3.2). Moreover, it is also argued that UM variable satisfies the criteria for good sustainability indicators (See Section 5.1.4), which implies that UM could be applied to develop indicators for measuring urban sustainability (US) and assessing the progress of sustainable development (SD).

The second role of UM in EMUP is urban typologies benchmarks. According to Asian Development Bank (ADB) (2014), urban typologies (or signature) are defined by the development of particular economic activities within cities' boundaries, including jobs, economic output, external material resource dependency; and, depending on how they process the resources, impact on the environment. Deeper understanding of how natural resource use interacts with urban economic activities is a key to SD and assessing their interactions is the role of the emerging field of $\mathrm{UM}^{121}$. When evaluated against economic, climate, demographic, urban morphology, and governance data, urban metabolism indicators can characterize urban typologies and benchmark each city to the relative resource 
intensity of the economic sectors (ADB, 2014).

In a word, the role of UM in environmental management \& urban planning in relation to urban sustainability (US) $\&$ smart cities (SC) are a) assessing the performance, material \& resources flows and dynamics of US \& SC and b) indicating the development progresses of SC \& attainments of building US.

\subsection{US as a Baseline}

UM approaches like ecological footprint analysis (EFA), have triggered the consideration of the "carrying capacity" of a particular ecosystem which represents one of the cornerstones of sustainable development (SD) (Melosi, 2009). Since SD incorporates urban sustainability (US) and vice versa, US practice can be considered as a basis of UM as well. On the other hand, US can be considered as an intangible baseline of smart cities (SC) (See section 7.1.2). Smart cities (SC) and sustainable urban development (SUD) contribute to each other in the ways that technological infrastructures of SC act as a platform for building up SUD. SUD is a critical necessary precondition of UM; hence, it can be seen as a mutually reinforcing relationship between US \& SC as well as SC \& SUD.

\subsection{SC as a Platform}

Smart cities (SC) focus on technological improvements to optimize a city's performance and services. The construction of SC is believed to provide opportunities for both urban metabolism (UM) \& urban sustainability (US) (See Section 7.1.3). SC promotes and reinforces sustainable urban development (SUD) while SUD is a major critical actor in achieving urban sustainability (US). Thus, SC provides the technological base for constructing up US (See section 7.1.2). Furthermore, the data collected by smart cities (SC)' information \& communication technology (ICT) services can also be used to assess UM and the improvements made by smart urban technologies will eventually boost the city's UM functions directly or indirectly. That is to say, SC provides a platform for building US and improving UM.

\section{Conclusion}

In this Anthropocene Era, human activities are recognized as the main driving factors of global challenges \& major environmental crisis on this planet. Those challenges \& crisis involve climate change, resource management, environmental degradation, biodiversity loss, social inequality and so on. Despite this it seems global urbanization and anthropogenic impacts on the planet are irreversible, Sustainable Development Goals (SDGs) are perceived as the blueprint to accomplish a more sustainable future and sustainable urban development (SUD) is seen as a panacea for the global major challenges our present generation are facing. Consequently, reducing anthropogenic impacts and resolving challenges in achieving urban sustainability (US) (and/or SUD) have been recognized as the central of environmental management concerns nowadays. Since cities are the centre of human activities and the world's most population live in the cities, it leaves a clue for searching the silver lining in the cities/urban systems.

In conclusion, this paper identifies urban metabolism (UM) as a potential approach to generate solution for the current global major challenges with discussions about smart cities (SC), urban sustainability (US), sustainable urban development (SUD), sustainable development, circular economy, circular UM, data politics and etc. The importance of UM has been demonstrated in this paper and its potential for resolving global major challenges \& environmental management issues has been proved by revealing its implications on US (and /or SUD) and SC. Developing a unified UM approach for all cities and implementing circular UM with the aid of SC technologies is an imperative move towards US (and/or SUD). The proposed Nexus of UM-US-SC underlines the mutually beneficial relationship among those three elements and connotes the need for an integrated approach may be the greatest way to reduce the impacts of anthropological activities on our planet and resolve the challenges \& difficulties for building US \& SC simultaneously in order to achieve planetary sustainability at all level.

Further research work might include standardization of UMA method, implementation of UM for all cities, solving the data availability issue for UMAs, moving from top-down to bottom-up approach, integrating SC technologies with assessing \& monitoring of UM variables/indicators, exploring the UM-US-SC Nexus further with respect to environmental management, urban planning, policy making and etc.

\section{Acknowledgements}

This paper is my MEM (Master of Environmental Management) research project (IEST 8024) as part of UNSW MEM program. I would like to express my deep gratitude to my research supervisor A/Prof Paul Brown, for this patient guidance, enthusiastic encourage, valuable suggestions and useful critiques of this research project. His willingness to give his time so generously has been very much appreciated. 


\section{References}

Ahvenniemi, H., Huovila, A., Pinto-Seppä, I., \& Airaksinen, M. (2017). What are the differences between sustainable and smart cities?. Cities, 60, 234-245. https://doi.org/10.1016/j.cities.2016.09.009

Alberti, M. (1996). Measuring urban sustainability. Environmental Impact Assessment Review, 16(4-6), 381-424. https://doi.org/10.1016/s0195-9255(96)00083-2

Albino, V., Berardi, U., \& Dangelico, R. M. (2015). Smart Cities: Definitions, Dimensions, Performance, and Initiatives. Journal of Urban Technology, 22(1), 3-21. https://doi.org/10.1080/10630732.2014.942092

Anderberg, S. (1998). Industrial metabolism and the linkages between economics, ethics and the environment1Workshop on Economics, Ethics and Environment. Ecological Economics, 24(2), 311-320. https://doi.org/10.1016/S0921-8009(97)00151-1

Angelidou, M. (2014). Smart city policies: A spatial approach. Cities, 41, S3-S11. https://doi.org/10.1016/j.cities.2014.06.007

Anthopoulos, L. (2017). Smart utopia VS smart reality: Learning by experience from 10 smart city cases. Cities, 63, 128-148. https://doi.org/10.1016/j.cities.2016.10.005

Aragona, B., \& De Rosa, R. (2018). Big data in policy making. Mathematical Population Studies, 1-7. https://doi.org/10.1080/08898480.2017.1418113

Ascione, M., Campanella, L., Cherubini, F., \& Ulgiati, S. (2009). Environmental driving forces of urban growth and development: An emergy-based assessment of the city of Rome, Italy. Landscape and Urban Planning, 93(3), 238-249. https://doi.org/10.1016/j.landurbplan.2009.07.011

Baccini, P. (1991). Metabolism of the anthroposphere. New York : Springer-Verlag.

Baccini, P. (1997). A city's metabolism: Towards the sustainable development of urban systems. Journal of Urban Technology, 4(2), 27-39. https://doi.org/10.1080/10630739708724555

Bai, X. (2007). Industrial Ecology and the Global Impacts of Cities. Journal of Industrial Ecology, 11(2), 1-6. https://doi.org/10.1162/jie.2007.1296

Baig, Z. A., Szewczyk, P., Valli, C., Rabadia, P., Hannay, P., Chernyshev, M., . . Peacock, M. (2017). Future challenges for smart cities: Cyber-security and digital forensics. Digital Investigation, 22, 3-13. https://doi.org/10.1016/j.diin.2017.06.015

Barlas, Y., \& Yasarcan, H. (2006). Goal setting, evaluation, learning and revision: A dynamic modeling approach. Eval. Program Plan., 29(1), 79-87. https://doi.org/10.1016/j.evalprogplan.2005.08.003

Barles, S. (2009). Urban Metabolism of Paris and Its Region. Journal of Industrial Ecology, 13(6), 898-913. https://doi.org/10.1111/j.1530-9290.2009.00169.x

Barles, S. (2010). Society, energy and materials: the contribution of urban metabolism studies to sustainable urban development issues. Journal of Environmental Planning and Management, 53(4), 439-455. https://doi.org/10.1080/09640561003703772

Batty, M. (2013). Big data, smart cities and city planning. Dialogues in Human Geography, 3(3), 274-279. https://doi.org/10.1177/2043820613513390

Beloin-Saint-Pierre, D., Rugani, B., Lasvaux, S., Mailhac, A., Popovici, E., Sibiude, G., . . Schiopu, N. (2017). A review of urban metabolism studies to identify key methodological choices for future harmonization and implementation. Journal of Cleaner Production, 163, S223-S240. https://doi.org/10.1016/j.jclepro.2016.09.014

Bibri, S. E., \& Krogstie, J. (2017). On the social shaping dimensions of smart sustainable cities: A study in science, technology, and society. Sustainable Cities and Society, 29, 219-246. https://doi.org/10.1016/j.scs.2016.11.004

Blečić, I., Cecchini, A., Falk, M., Marras, S., Pyles, D. R., Spano, D., \& Trunfio, G. A. (2014). Urban metabolism and climate change: A planning support system. International Journal of Applied Earth Observation and Geoinformation, 26, 447-457. https://doi.org/10.1016/j.jag.2013.08.006

Booch, G. (2014). The Human and Ethical Aspects of Big Data. IEEE Software, 31(1), 20-22. https://doi.org/10.1109/MS.2014.16

Brand, F. (2009). Critical natural capital revisited: Ecological resilience and sustainable development. Ecological 
Economics, 68(3), 605-612. https://doi.org/10.1016/j.ecolecon.2008.09.013

Braun, T., Fung, B. C. M., Iqbal, F., \& Shah, B. (2018). Security and privacy challenges in smart cities. Sustainable Cities and Society, 39, 499-507. https://doi.org/10.1016/j.scs.2018.02.039

Bristow, D. N., \& Kennedy, C. A. (2013). Urban Metabolism and the Energy Stored in Cities: Implications for Resilience Bristow and Kennedy The Energy Stored in Cities. Journal of Industrial Ecology, 17(5). https://doi.org/10.1111/jiec.12038

Broto, V. C., Allen, A., \& Rapoport, E. (2012). Interdisciplinary Perspectives on Urban Metabolism. Journal of Industrial Ecology, 16(6), 851-861. https://doi.org/10.1111/j.1530-9290.2012.00556.x

Brown, M. T., \& Ulgiati, S. (2004). Energy quality, emergy, and transformity: H.T. Odum's contributions to quantifying and understanding systems. Ecological Modelling, 178(1), 201-213. https://doi.org/10.1016/j.ecolmodel.2004.03.002

Browne, D., O'Regan, B., \& Moles, R. (2009). Assessment of total urban metabolism and metabolic inefficiency in an Irish city-region. Waste management (New York, N.Y.), 29(10), 2765. https://doi.org/10.1016/j.wasman.2009.05.008

Brunner, P. H. (2001). Materials Flow Analysis: Vision and Reality. Journal of Industrial Ecology, 5(2), 3-5. https://doi.org/10.1162/10881980152830088

Buchanan, E. (2017). Considering the ethics of big data research: A case of Twitter and ISIS/ISIL. PLoS One, 12(12), e0187155. https://doi.org/10.1371/journal.pone.0187155

Cave, J. (2016). The ethics of data and of data science: an economist's perspective. Philosophical Transactions. Series A, Mathematical, Physical, and Engineering Sciences, 374(2083). https://doi.org/10.1098/rsta.2016.0117

Céspedes Restrepo, J. D., \& Morales-Pinzón, T. (2018). Urban metabolism and sustainability: Precedents, genesis and research perspectives. Resources, Conservation and Recycling, 131, 216-224. https://doi.org/10.1016/j.resconrec.2017.12.023

Chen, B. (2015). Integrated ecological modelling for sustainable urban metabolism and management. Ecological Modelling, 318, 1-4. https://doi.org/10.1016/j.ecolmodel.2015.10.009

Chrysoulakis, N., Lopes, M., San José, R., Grimmond, C. S. B., Jones, M. B., Magliulo, V., . . Cartalis, C. (2013). Sustainable urban metabolism as a link between bio-physical sciences and urban planning: The BRIDGE project. Landscape and Urban Planning, 112, 100-117. https://doi.org/10.1016/j.landurbplan.2012.12.005

Codoban, N., \& Kennedy, C. (2008). Metabolism of neighborhoods. J. Urban Plan. Dev.-ASCE, 134(1), 21-31. https://doi.org/10.1061/(ASCE)0733-9488(2008)134:1(21)

Cohen, M. (2017). A systematic review of urban sustainability assessment literature. Sustainability (Switzerland), 9(11). https://doi.org/10.3390/su9112048

Conke, L. S., \& Ferreira, T. L. (2015). Urban metabolism: Measuring the city's contribution to sustainable development. Environmental Pollution, 202, 146-152. https://doi.org/10.1016/j.envpol.2015.03.027

Conroy, M. M., \& Berke, P. R. (2004). What Makes a Good Sustainable Development Plan? An Analysis of Factors That Influence Principles of Sustainable Development. Environment and Planning A: Economy and Space, 36(8), 1381-1396. https://doi.org/10.1068/a367

Corburn, J. (2017). Sustainability Illustrated. (2014, April 8). Triple bottom line \& sustainability: the science of good business [online video]. Retrieved from https://www.youtube.com/watch? $\mathrm{v}=2 \mathrm{f5m}-\mathrm{jBf} 81 \mathrm{Q} \& \mathrm{t}=18 \mathrm{~s}$

Cui, X. (2018). How can cities support sustainability: A bibliometric analysis of urban metabolism. Ecological Indicators, 93, 704-717. https://doi.org/10.1016/j.ecolind.2018.05.056

Currie, M. E., Paris, B. S., \& Donovan, J. M. (2018). What difference does data make? Data management and social change. Online Information Review. https://doi.org/10.1108/OIR-02-2018-0052

Currie, P. K., \& Musango, J. K. (2017). African Urbanization: Assimilating Urban Metabolism into Sustainability Discourse and Practice. Journal of Industrial Ecology, 21(5), 1262-1276. https://doi.org/10.1111/jiec.12517

Currie, P. K., Musango, J. K., \& May, N. D. (2017). Urban metabolism: A review with reference to Cape Town. Cities, 70, 91-110. https://doi.org/10.1016/j.cities.2017.06.005

Dakhia, K., \& Berezowska-Azzag, E. (2010). Urban institutional and ecological footprint. Management of 
$\begin{array}{lllll}\text { Environmental Quality: An } \quad \text { International } & \text { Journal, }\end{array}$ https://doi.org/10.1108/14777831011010874

Davoudi, S., \& Sturzaker, J. (2017). Urban form, policy packaging and sustainable urban metabolism. Resources, Conservation and Recycling, 120, 55-64. https://doi.org/10.1016/j.resconrec.2017.01.011

De Groot, R., Van der Perk, J., Chiesura, A., \& van Vliet, A. (2003). Importance and threat as determining factors for criticality of natural capital'. Ecological Economics, 44, 187-204.

Decker, E. H., Elliott, S., Smith, F. A., Blake, D. R., \& Rowland, F. S. (2000). ENERGY AND MATERIAL FLOW THROUGH THE URBAN ECOSYSTEM. Annual Review of Energy \& the Environment, 25(1), 685.

Dedeurwaerdere, T. (2014). Sustainability Science for Strong Sustainability. Northampton: Edward Elgar.

Dijst, M., Worrell, E., Böcker, L., Brunner, P., Davoudi, S., Geertman, S., . . Zeyringer, M. (2018). Exploring urban metabolism-Towards an interdisciplinary perspective. Resources, Conservation and Recycling, 132, 190-203. https://doi.org/10.1016/j.resconrec.2017.09.014

Dijst, M., Worrell, E., Böcker, L., Brunner, P., Davoudi, S., Geertman, S., . . Zeyringer, M. (2018). Exploring urban metabolism-Towards an interdisciplinary perspective. Resources, Conservation and Recycling, 132, 190-203. https://doi.org/10.1016/j.resconrec.2017.09.014

Docherty, A. (2014). Big Data - ethical perspectives. Anaesthesia, 69(4), 390-391. https://doi.org/10.1111/anae.12656

Doughty, M., \& Hammond, G. P. (2004). Sustainability and the built environment at and beyond the city scale. Build. Environ., 39(10), 1223-1233. https://doi.org/10.1016/j.buildenv.2004.03.008

Dubey, R., Gunasekaran, A., Childe, S. J., Papadopoulos, T., Luo, Z., Wamba, S. F., \& Roubaud, D. (2017). Can big data and predictive analytics improve social and environmental sustainability?. Technological Forecasting and Social Change. https://doi.org/10.1016/j.techfore.2017.06.020

Ekins, P., Simon, S., Deutsch, L., Folke, C., \& De Groot, R. (2003). A framework for the practical application of the concepts of critical natural capital and strong sustainability. Ecological Economics, 44(2), 165-185. https://doi.org/10.1016/S0921-8009(02)00272-0

Engel-Yan, J., Kennedy, C., Saiz, S., \& Pressnail, K. (2005). Toward sustainable neighbourhoods: the need to consider infrastructure interactions. Canadian Journal of Civil Engineering, 32(1), 45-57. https://doi.org/10.1139/104-116

Fernández, P. F. A. J. (2013). Sustainable Urban Metabolism. London, England: The MIT Press.

Ferrão, P., \& Fernández, J. E. (2013). Sustainable Urban Metabolism. Cambridge: MIT Press.

García-Guaita, F., González-García, S., Villanueva-Rey, P., Moreira, M. T., \& Feijoo, G. (2018). Integrating Urban Metabolism, Material Flow Analysis and Life Cycle Assessment in the environmental evaluation of Santiago de Compostela. Sustainable Cities and Society, 40, 569-580. https://doi.org/10.1016/j.scs.2018.04.027

Gelobter, M. (1994). The Meaning of Urban Environmental Justice. Fordham Urban Law Journal, 21(3), 841-865.

Gemenetzi, G. (2013). Improving urban metabolism through spatial planning: a methodology of eco-development. Retrieved from https://www.gnest.org/proceedings/cest2013/public_html/papers/0223.pdf

Geng, Y., Zhang, L., Chen, X., Xue, B., Fujita, T., \& Dong, H. (2014). Urban ecological footprint analysis: a comparative study between Shenyang in China and Kawasaki in Japan. Journal of Cleaner Production, 75, 130-142. https://doi.org/10.1016/j.jclepro.2014.03.082

Giampietro, M., Mayumi, K., \& Ramos-Martin, J. (2009). Multi-scale integrated analysis of societal and ecosystem metabolism (MuSIASEM): Theoretical concepts and basic rationale. Energy, 34(3), 313-322. https://doi.org/10.1016/j.energy.2008.07.020

Goldstein, B., Birkved, M., Quitzau, M.-B., \& Hauschild, M. (2013). Quantification of urban metabolism through coupling with the life cycle assessment framework: concept development and case study. Environmental Research Letters, 8(3), 035024. https://doi.org/10.1088/1748-9326/8/3/035024

Golubiewski, N. (2012). Is There a Metabolism of an Urban Ecosystem? An Ecological Critique. A Journal of the Human Environment, 41(7), 751-764. https://doi.org/10.1007/s13280-011-0232-7 
González, A., Donnelly, A., Jones, M., Chrysoulakis, N., \& Lopes, M. (2013). A decision-support system for sustainable urban metabolism in Europe. Environmental Impact Assessment Review, 38, 109-119. https://doi.org/10.1016/j.eiar.2012.06.007

Goonetilleke, A., Yigitcanlar, T., Ayoko, G. A., Egodawatta, P. (2014). Sustainable Urban Water nvironment. Edward Elgar: London.

Guibrunet, L., Calvet, M. S., \& Broto, V. (2017). Flows, system boundaries and the politics of urban metabolism: Waste management in Mexico City and Santiago de Chile. Geoforum, 85, 353-367. https://doi.org/10.1016/j.geoforum.2016.10.011

Gunawan, J., \& Pusaka, S. (2016). Introducing the Urban Metabolism Approach for a Sustainable City: A Case of Jakarta, Indonesia. Journal of Applied Management Accounting Research, 14(1), 55-68.

Gutiérrez, M. (2018). Data Activism and Social Change. Cham: Springer International Publishing: Imprint: Palgrave Pivot.

Hamman, P., Anquetin, V., \& Monicolle, C. (2017). Contemporary Meanings of the 'Sustainable City': A Comparative Review of the French- and English-Language Literature. Sustainable Development, 25(4), 336-355. https://doi.org/10.1002/sd.1660

Han, G., Guizani, M., Lloret, J., Chan, S., Wan, L., \& Guibene, W. (2017). Emerging Trends, Issues, and Challenges in Big Data and Its Implementation toward Future Smart Cities. IEEE Communications Magazine, 55(12), 16-17. https://doi.org/10.1109/MCOM.2017.8198795

Han, W., Geng, Y., Lu, Y., Wilson, J., Sun, L., Satoshi, O., . . Qian, Y. (2018). Urban metabolism of megacities: A comparative analysis of Shanghai, Tokyo, London and Paris to inform low carbon and sustainable development pathways. Energy, 155, 887-898. https://doi.org/10.1016/j.energy.2018.05.073

Harvránek, M. (2008). What is ConAccount. Retrieved from https://www.czp.cuni.cz/ConAccount/view.php?nazevclanku=what-is-conaccount\&cisloclanku=200801000 2

Hiller, J., \& Blanke, J. (2017). Smart Cities, Big Data, and the Resilience of Privacy. Hastings Law J., 68(2), 309-356.

Hoekman, P., \& Blottnitz, H. (2017). Cape Town's Metabolism: Insights from a Material Flow Analysis. Journal of Industrial Ecology, 21(5), 1237-1249. https://doi.org/10.1111/jiec.12508

Huang, W., Cui, S., Yarime, M., Hashimoto, S., \& Managi, S. (2015). Improving urban metabolism study for sustainable urban transformation. Environmental Technology \& Innovation, 4, 62-72. https://doi.org/10.1016/j.eti.2015.04.004

Ibrahim, M., El-Zaart, A., \& Adams, C. (2018). Smart sustainable cities roadmap: Readiness for transformation towards urban sustainability. Sustainable Cities and Society, 37, 530-540. https://doi.org/10.1016/j.scs.2017.10.008

Inostroza, L. (2014). Measuring urban ecosystem functions through 'Technomass'-A novel indicator to assess urban metabolism. Ecological Indicators, 42, 10-19. https://doi.org/10.1016/j.ecolind.2014.02.035

Ismail, A. (2016, 15-16 March 2016). Utilizing big data analytics as a solution for smart cities. Paper presented at the 2016 3rd MEC International Conference on Big Data and Smart City (ICBDSC).

Kennedy, C., Baker, L., Dhakal, S., \& Ramaswami, A. (2012). Sustainable Urban Systems An Integrated Approach. J. Ind. Ecol., 16(6), 775-779. https://doi.org/10.1111/j.1530-9290.2012.00564.x

Kennedy, C., Cuddihy, J., \& Engel-Yan, J. (2007). The Changing Metabolism of Cities. Journal of Industrial Ecology, 11(2), 43-59. https://doi.org/10.1162/jie.2007.1107

Kennedy, C., Pincetl, S., \& Bunje, P. (2011). The study of urban metabolism and its applications to urban planning and design. Environmental Pollution, 159(8), 1965-1973. https://doi.org/10.1016/j.envpol.2010.10.022

Kennedy, C., Stewart, I. D., Ibrahim, N., Facchini, A., \& Mele, R. (2014). Developing a multi-layered indicator set for urban metabolism studies in megacities. Ecological Indicators, 47, 7-15. https://doi.org/10.1016/j.ecolind.2014.07.039

Kennedy, C., Stewart, I., Facchini, A., Cersosimo, I., Mele, R., Chen, B., .. . Sahin, A. (2015). Energy and material flows of megacities. Proceedings of the National Academy of Sciences of the United States of America, $112(19), 5985$. 
Kitchin, R. (2014a). Big Data, new epistemologies and paradigm shifts. Big Data \& Society, 1(1), 2053951714528481. https://doi.org/10.1177/2053951714528481

Kitchin, R. (2014b). The real-time city? Big data and smart urbanism. GeoJournal, 79(1), 1-14.

Komninos, N. (2016). Smart environments and smart growth: connecting innovation strategies and digital growth strategies. International Journal of Knowledge-Based Development, 7(3), 240-263.

Kovacic, Z., \& Giampietro, M. (2017). Between theory and quantification: An integrated analysis of metabolic patterns of informal urban settlements. Energy Policy, 100(C), 377-386. https://doi.org/10.1016/j.enpol.2016.06.047

Kudva, S., \& Ye, X. (2017). Smart Cities, Big Data, and Sustainability Union. Big Data and Cognitive Computing, l(1). https://doi.org/10.3390/bdcc1010004

Kunzmann, K. R. (2014). Smart Cities: A New Paradigm of Urban Development, Crios, 4(1), 9-20.

Lacinák, M., \& Ristvej, J. (2017). Smart City, Safety and Security. Procedia Engineering, 192, 522-527. https://doi.org/10.1016/j.proeng.2017.06.090

Lederer, J., \& Kral, U. (2015). Theodor Weyl: A Pioneer of Urban Metabolism Studies. Journal of Industrial Ecology, 19(5), 695-702. https://doi.org/10.1111/jiec.12320

Lei, K., Liu, L., Hu, D., \& Lou, I. (2016). Mass, energy, and emergy analysis of the metabolism of Macao. Journal of Cleaner Production, 114, 160-170. https://doi.org/10.1016/j.jclepro.2015.05.099

Lenzen, M., Dey, C., \& Foran, B. (2004). Energy requirements of Sydney households. Ecological Economics, 49(3), 375-399. https://doi.org/10.1016/j.ecolecon.2004.01.019

Li, H., \& Kwan, M.-P. (2018). Advancing analytical methods for urban metabolism studies. Resources, Conservation and Recycling, 132, 239-245. https://doi.org/10.1016/j.resconrec.2017.07.005

Liang, S., \& Zhang, T. (2011). Urban Metabolism in China Achieving Dematerialization and Decarbonization in Suzhou. Journal of Industrial Ecology, 15(3), 420-434. https://doi.org/10.1111/j.1530-9290.2011.00343.x

Lu, Y., Geng, Y., Qian, Y., Han, W., McDowall, W., \& Bleischwitz, R. (2016). Changes of human time and land use pattern in one mega city's urban metabolism: a multi-scale integrated analysis of Shanghai. Journal of Cleaner Production, 133, 391-401. https://doi.org/10.1016/j.jclepro.2016.05.174

Lyons, G., Mokhtarian, P., Dijst, M., \& Böcker, L. (2018). The dynamics of urban metabolism in the face of digitalization and changing lifestyles: Understanding and influencing our cities. Resources, Conservation and Recycling, 132, 246-257. https://doi.org/10.1016/j.resconrec.2017.07.032

Martin, C. J., Evans, J., \& Karvonen, A. (2018). Smart and sustainable? Five tensions in the visions and practices of the smart-sustainable city in Europe and North America. Technological Forecasting and Social Change, 133, 269-278. https://doi.org/10.1016/j.techfore.2018.01.005

Marx, K. (1887). A Critique of Political Ecolomy. Vol I Book One: The Process of Production of Capital. Moscow: Progress Publishers.

Marx, K. (1981). Capital. Vol. III. London: Penguin Books.

Melosi, M. V. (2009). Humans, Cities, and Nature: How Do Cities Fit in the Material World?. Journal of Urban History, 36(1), 3-21. https://doi.org/10.1177/0096144209349876

Moore, J., Kissinger, M., \& Rees, W. E. (2013). An urban metabolism and ecological footprint assessment of Metro Vancouver. Journal of Environmental Management, 124, 51-61. https://doi.org/10.1016/j.jenvman.2013.03.009

Moore, S. A. (2007). In the Nature of Cities: Urban Political Ecology and the Politics of Urban Metabolism. Nik Heynen, Maria Kaika, and Erik Swyngedouw, eds. Urban Geography, 28(2), 206-208. https://doi.org/10.2747/0272-3638.28.2.206

Mostafavi, N., Farzinmoghadam, M., \& Hoque, S. (2014). A framework for integrated urban metabolism analysis tool (IUMAT). Building and Environment, 82, 702-712. https://doi.org/10.1016/j.buildenv.2014.10.020

Neirotti, P., De Marco, A., Cagliano, A. C., Mangano, G., \& Scorrano, F. (2014). Current trends in Smart City initiatives: Some stylised facts. Cities, 38, 25-36. https://doi.org/10.1016/j.cities.2013.12.010

Newell, J. P., \& Cousins, J. J. (2015). The boundaries of urban metabolism: Towards a political-industrial ecology. Progress in Human Geography, 39(6), 702-728. https://doi.org/10.1177/0309132514558442 
Newman, P. W. G. (1999). Sustainability and cities: extending the metabolism model. Landscape and Urban Planning, 44(4), 219-226. https://doi.org/10.1016/S0169-2046(99)00009-2

Niza, S., Rosado, L., \& Ferrão, P. (2009). Urban Metabolism (Vol. 13, pp. 384-405): Wiley-Blackwell.

Pelenc,J., Ballect, J. \& Dedeurwaerdere, T. (2015). Weak Sustainability versus Strong Sustainability. Retrieved from

https://sustainabledevelopment.un.org/content/documents/6569122-Pelenc-Weak\%20Sustainability\%20vers us\%20Strong\%20Sustainability.pdf

Pincetl, S. (2012). Nature, urban development and sustainability - What new elements are needed for a more $\begin{array}{lllll}\text { comprehensive } \quad \text { understanding?. } & \text { Cities, } & \text { 29(Supplement } & 2 \text { ), } & \text { S32-S37. }\end{array}$ https://doi.org/10.1016/j.cities.2012.06.009

Pincetl, S., Bunje, P., \& Holmes, T. (2012). An expanded urban metabolism method: Toward a systems approach for assessing urban energy processes and causes. Landscape and Urban Planning, 107(3), 193-202. https://doi.org/10.1016/j.landurbplan.2012.06.006

Pulido Barrera, P., Rosales Carreón, J., \& de Boer, H. J. (2018). A multi-level framework for metabolism in urban energy systems from an ecological perspective. Resources, Conservation and Recycling, 132, 230-238. https://doi.org/10.1016/j.resconrec.2017.05.005

Ravalde, T., \& Keirstead, J. (2017). Comparing performance metrics for multi-resource systems: the case of urban metabolism. Journal of Cleaner Production, 163, S241-S253. https://doi.org/10.1016/j.jclepro.2015.10.118

Rees, W. E. (2003). Understanding Urban Ecosystems: An Ecological Economics Perspective. Understanding Urban Ecosystem. New York: Springer.

Rees, W., \& Wackernagel, M. (1996). Urban ecological footprints: Why cities cannot be sustainable - and why they are a key to sustainability. Environmental Impact Assessment Review, 16(4-6), 223-248. https://doi.org/10.1016/S0195-9255(96)00022-4

Richterich, A. (2018). The Big Data Agenda: Data Ethics and Critical Data Studies: University of Westminster Press.

Rosado, L., Kalmykova, Y., \& Patrício, J. (2016). Urban metabolism profiles. An empirical analysis of the material flow characteristics of three metropolitan areas in Sweden. Journal of Cleaner Production, 126, 206-217. https://doi.org/10.1016/j.jclepro.2016.02.139

Rosales Carreón, J., \& Worrell, E. (2018). Urban energy systems within the transition to sustainable development. A research agenda for urban metabolism. Resources, Conservation and Recycling, 132, 258-266. https://doi.org/10.1016/j.resconrec.2017.08.004

Rushil, S. M., John, H., \& Andrea, M. B. (2009). Using an Integrated Participatory Modeling Approach to Assess Water Management Options and Support Community Conversations on Maui. Sustainability, 1(4), 1331-1348. https://doi.org/10.3390/su1041331

Sahely, H. R., Dudding, S., \& Kennedy, C. A. (2003). Estimating the urban metabolism of Canadian cities: Greater Toronto Area case study. Canadian Journal of Civil Engineering, 30(2), 468.

Shu-Li, H., \& Chia-Wen, C. (2009). Urbanization and Socioeconomic Metabolism in Taipei. Journal of Industrial Ecology, 13(1), 75-93. https://doi.org/10.1111/j.1530-9290.2008.00103.x

Shwayri, S. T. (2013). A Model Korean Ubiquitous Eco-City? The Politics of Making Songdo. Journal of Urban Technology, 20(1), 39-55. https://doi.org/10.1080/10630732.2012.735409

Sierra Forest Legacy. (2012). Triple Bottom Line [Image]. Retrieved from https://www.sierraforestlegacy.org/CF_Sustainability/Sustainability.php

Silver, J., \& Marvin, S. (2016). Powering sub-Saharan Africa's urban revolution: An energy transitions approach. Urban Studies, 54(4), 847-861. https://doi.org/10.1177/0042098016668105

Song, M., Cen, L., Zheng, Z., Fisher, R., Liang, X., Wang, Y., \& Huisingh, D. (2017). How would big data support societal development and environmental sustainability? Insights and practices. J. Clean Prod., 142, 489-500. https://doi.org/10.1016/j.jclepro.2016.10.091

Sun, L., Dong, H., Geng, Y., Li, Z., Liu, Z., Fujita, T., . . Fujii, M. (2016). Uncovering driving forces on urban metabolism-A case of Shenyang. Journal of Cleaner Production, 114, 171-179. https://doi.org/10.1016/j.jclepro.2015.05.053 
Sustainable Development Solutions Network. (2013). Why The World Needs An Urban Sustainable Development Goal. Retrieved from https://sustainabledevelopment.un.org/content/documents/2569130918-SDSN-Why-the-World-Needs-an-U rban-SDG.pdf

Taamallah, A., Khemaja, M., \& Faiz, S. (2017). Strategy ontology construction and learning: insights from smart city strategies. International Journal of Knowledge-Based Development, 8(3), 206-228.

Thakuriah, P., Tilahun, N., \& Zellner, M. (2017). Seeing Cities Through Big Data : Research, Methods and Applications in Urban Informatics: Cham : Springer International Publishing.

Thomson, G., \& Newman, P. (2018). Urban fabrics and urban metabolism - from sustainable to regenerative cities. Resources, Conservation and Recycling, 132, 218-229. https://doi.org/10.1016/j.resconrec.2017.01.010

Thwink.org. (2014). Two ways to visualize the three pillars [Image]. Retrieved from http://www.thwink.org/sustain/glossary/ThreePillarsOfSustainability.htm

Townsend, A. M. (2013). Smart cities : big data, civic hackers, and the quest for a new utopia (1st ed.). New York, NY : W.W. Norton \& Company, Inc.

Trindade, E. P., Hinnig, M. P. F., da Costa, E. M., Marques, J. S., Bastos, R. C., \& Yigitcanlar, T. (2017). Sustainable development of smart cities: a systematic review of the literature. Journal of Open Innovation: Technology, Market, and Complexity, 3(1), 11. https://doi.org/10.1186/s40852-017-0063-2

Troy, P. (2013). Urban sustainability. Economic and Labour Relations Review, 24(4), 469-480. https://doi.org/10.1177/1035304613510232

Ulgiati, S., Ascione, M., Zucaro, A., \& Campanella, L. (2011). Emergy-based complexity measures in natural and

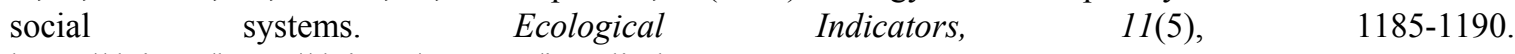
https://doi.org/https://doi.org/10.1016/j.ecolind.2010.12.021

UN. (2013). Pillars for achieving sustainability of cities [Image]. Retrieved from http://www.un.org/en/development/desa/policy/wess/wess_current/wess2013/Chapter3.pdf

United Nations. (2013). World Economic and Social Survey 2013 Chapter III Towards sustainable cities. Retrieved from http://www.un.org/en/development/desa/policy/wess/wess_current/wess2013/Chapter3.pdf

University of Alberta Office of Sustainability. (n.d.). What is sustainability? Retrieved from https://www.mcgill.ca/sustainability/files/sustainability/what-is-sustainability.pdf

Van den Hove, S. (2000). Participatory approaches to environmental policy-making: the European Commission Climate Policy Process as a case study. Ecological Economics, 33, 457-472.

Van Zoonen, L. (2016). Privacy concerns in smart cities. Government Information Quarterly, 33(3), 472-480. https://doi.org/10.1016/j.giq.2016.06.004

Vanolo, A. (2013). Smartmentality: The Smart City as Disciplinary Strategy. Urban Studies, 51(5), 883-898. https://doi.org/10.1177/0042098013494427

Verma, P., \& Raghubanshi, A. S. (2018). Urban sustainability indicators: Challenges and opportunities. Ecological Indicators, 93, 282-291. https://doi.org/10.1016/j.ecolind.2018.05.007

Weisz, H., \& Steinberger, J. (2010). Reducing energy and material flows in cities. Curr. Opin. Environ. Sustain., 2(3), 185-192. https://doi.org/10.1016/j.cosust.2010.05.010

Wolman, A. (1965). THE METABOLISM OF CITIES. Scientific American, 213, 179.

World Commission on Environment and Development. (1987). Report of the world commission on environment and development: Our common future. United Nations. Retrieved from http://www.un-documents.net/our-common-future.pdf

Yetano Roche, M., Lechtenbhmer, S., Fischedick, M., Grne, M.-C., Xia, C., \& Dienst, C. (2014). Concepts and Methodologies for Measuring the Sustainability of Cities. Annu. Rev. Environ. Resour., 39(1), 519-547. https://doi.org/10.1146/annurev-environ-012913-101223

Yigitcanlar, T. (2015). Smart cities: an effective urban development and management model?. Australian Planner, 52(1), 1-8. https://doi.org/10.1080/07293682.2015.1019752

Yigitcanlar, T., \& Kamruzzaman, M. (2018). Does smart city policy lead to sustainability of cities?. Land Use Policy, 73, 49-58. https://doi.org/10.1016/j.landusepol.2018.01.034 
Yigitcanlar, T., \& Teriman, S. (2015). Rethinking sustainable urban development: towards an integrated planning and development process. International Journal of Environmental Science and Technology, 12(1), 341-352. https://doi.org/10.1007/s13762-013-0491-x

Yuan, Z., Shi, J., Wu, H., Zhang, L., \& Bi, J. (2011). Understanding the anthropogenic phosphorus pathway with substance flow analysis at the city level. Journal of Environmental Management, 92(8), 2021. https://doi.org/10.1016/j.jenvman.2011.03.025

Zaccai, E. (2012). Over two decades in pursuit of sustainable development: Influence, transformations, limits. Environmental Development, 1(1), 79-90. https://doi.org/10.1016/j.envdev.2011.11.002

Zhang, Y. (2013). Urban metabolism: A review of research methodologies. Environmental Pollution, 178, 463-473. https://doi.org/10.1016/j.envpol.2013.03.052

Zhang, Y., Yang, Z., \& Yu, X. (2015). Urban Metabolism: A Review of Current Knowledge and Directions for

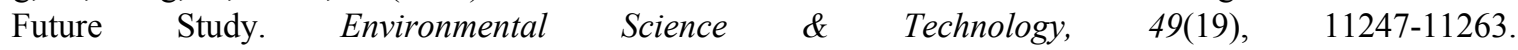
https://doi.org/10.1021/acs.est.5b03060

Zhang, Y., Yang, Z., Liu, G., \& Yu, X. (2011). Emergy analysis of the urban metabolism of Beijing. Ecological Modelling, 222(14), 2377-2384. https://doi.org/10.1016/j.ecolmodel.2010.09.017

Zhao, J. (2011). Towards Sustainable Cities in China. Berlin: Springer.

\section{Copyrights}

Copyright for this article is retained by the author(s), with first publication rights granted to the journal.

This is an open-access article distributed under the terms and conditions of the Creative Commons Attribution license (http://creativecommons.org/licenses/by/4.0/). 